The Netherlands

\title{
Age of rogues: transgressive politics at the frontiers of the Ottoman empire
}

Yenen, A.A.; Öztan, R.H.

\section{Citation}

Yenen, A. A., \& Öztan, R. H. (2021). Age of rogues: transgressive politics at the frontiers of the Ottoman empire. In Age of Rogues: Rebels, Revolutionaries and Racketeers at the Frontiers of Empires (pp. 3-52). Edinburgh: Edinburgh University Press. Retrieved from https://hdl.handle.net/1887/3210518

Version: $\quad$ Publisher's Version

License: $\quad$ Licensed under Article 25fa Copyright Act/Law (Amendment Taverne)

Downloaded from: https://hdl.handle.net/1887/3210518

Note: To cite this publication please use the final published version (if applicable). 
Chapter Title: Age of Rogues: Transgressive Politics at the Frontiers of the Ottoman Empire

Chapter Author(s): Alp Yenen and Ramazan Hakkı Öztan

Book Title: Age of Rogues

Book Subtitle: Rebels, Revolutionaries and Racketeers at the Frontiers of Empires

Book Editor(s): Ramazan Hakkı Öztan, Alp Yenen

Published by: Edinburgh University Press. (2021)

Stable URL: https://www.jstor.org/stable/10.3366/j.ctv1vtz871.7

JSTOR is a not-for-profit service that helps scholars, researchers, and students discover, use, and build upon a wide range of content in a trusted digital archive. We use information technology and tools to increase productivity and facilitate new forms of scholarship. For more information about JSTOR, please contact support@jstor.org.

Your use of the JSTOR archive indicates your acceptance of the Terms \& Conditions of Use, available at https://about.jstor.org/terms

Edinburgh University Press is collaborating with JSTOR to digitize, preserve and extend access to Age of Rogues 


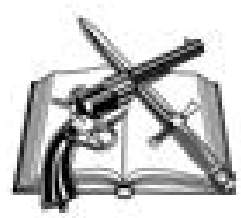


This content downloaded from 132.229.26.204 on Wed, 08 Sep 2021 07:41:54 UTC All use subject to https://about.jstor.org/terms 


\title{
Age of Rogues: \\ Transgressive Politics at the Frontiers of the Ottoman Empire
}

\author{
Alp Yenen and Ramazan Hakkı Öztan
}

magine an age of rogues marked by the clash of empires and a heightened level of interstate competition that spawns one insurgent group after another; when isolated yet authoritarian despots increasingly use coercion to contain opponents and rebels alike. Imagine an era when armed insurgents manipulate international rivalries for their own benefit, making extreme violence and irregular warfare the new routine of contentious politics - when rural insecurity and paramilitary violence, coupled with extreme demographic measures, create floods of refugees and a humanitarian crisis to which the responses of the international community of states remain fractured, reflective of their own interests that continue to fuel the conflict. Ultimately, imagine a time of contentious sociability out of which the rebels could one day emerge as rulers, while the latter might eventually turn into insurgents.

For many of us, imagining a time as such brings to mind recent images from Syria, if not from many other zones of conflict found across the global South today. ${ }^{1}$ This timely book will take its readers to an age of rogues in

\footnotetext{
${ }^{1}$ For an earlier comparison between the developments in the Ottoman Balkans and contemporary Middle East, see Ramazan Hakkı Öztan, 'Are We Witnessing the Macedonian Question of the 21st century?' Middle East Monitor, 16 October 2014, available at: https:// www.middleeastmonitor.com/20141016-are-we-witnessing-the-macedonian-question-ofthe-21st-century. See also: Barış Çaylı, Violence and Militants: From Ottoman Rebellions to Jihadist Organizations (Montreal: McGill-Queen's University Press, 2019).
} 
history that is neither near nor far - back to the turn of the twentieth century and to the frontiers of the Ottoman Empire, where, we claim, the way the contentious politics played out shaped the shaky foundations upon which the modern Balkans, Middle East and Caucasus were forged. ${ }^{2}$ What qualifies the turn of the twentieth century as particularly transformative is that it brought with it the collapse of the long-standing Romanov, Habsburg, Ottoman and Qajar empires. It was in their contentious frontiers that a variety of new political actors had emerged, playing crucial roles in the violent undoing of empires and the making of new nation-states.

We shall define the 'age of rogues' as a particular geopolitical and historical context within which imperial rivalries gave birth to a cast of parapolitical and paramilitary agents whose violent autonomy and culture of transgression managed to transform the legitimate norms of politics and the formal institutions of state sovereignty. We conspicuously label these actors as rogues, for the term is less concerned with the social status of non-state actors than its alternatives in the literature, such as 'subalterns', 'subversives' and 'dangerous classes'. ${ }^{3}$ Politically charged terms such as 'revolutionary', 'insurgent' or 'terrorist' do not fully capture the complex agency of non-state actors, either. ${ }^{4}$ Nor does 'paramilitarism', which, even though an important feature

${ }^{2}$ For a concise but comprehensive overview of this formative period, see Isa Blumi, Foundations of Modernity: Human Agency and the Imperial State (New York: Routledge, 2012). For contentious politics, see Charles Tilly and Sidney G. Tarrow, Contentious Politics (Boulder, CO: Paradigm, 2007). On the formative role of contentious politics in the history of the modern Middle East, see John Chalcraft, Popular Politics in the Making of the Modern Middle East (Cambridge: Cambridge University Press, 2016).

${ }^{3}$ Despite our terminological differences, these collections of articles should be considered as complementary with this volume. Edmund Burke, III and David Yaghoubian (eds), Struggle and Survival in the Modern Middle East, 2nd edn (Berkeley, CA: University of California Press, 2005); Stephanie Cronin (ed.), Subalterns and Social Protest: History from Below in the Middle East and North Africa (London: Routledge, 2008); Odile Moreau and Stuart Schaar (eds), Subversives and Mavericks in the Muslim Mediterranean: A Subaltern History (Austin: University of Texas Press, 2016); Stephanie Cronin (ed.), Crime, Poverty and Survival in the Middle East and North Africa: The 'Dangerous Classes' since 1800 (London: I. B. Tauris, 2019).

${ }^{4}$ As Jeremy Black proposes, global historians need to adopt a more fluid understanding of such categories of contentious politics and their state-led counterparts. Jeremy Black, Insurgency and Counterinsurgency: A Global History (Lanham, MD: Rowman \& Littlefield, 2016). 
of political violence, focuses on state-led armed actors alone. ${ }^{5}$ The ideological characterisation of 'nationalist', on the other hand, embodies pre-configured historical consequence, suffering from methodological nationalism. ${ }^{6}$ We instead call these actors 'rogues', since the term denotes agency in transgressive politics, while acknowledging multiplicity of interests - whether political, social or personal.

In designating their time as an age of rogues, however, we are not proposing yet another periodisation that may project a singular, linear and enclosed timeframe. Much to the contrary, we situate our actors within a world-historical setting of multiple and overlapping historical processes. ${ }^{7}$ As such, we maintain that the age of rogues in fact took place along with other related ages of 'empire', 'Western domination', 'nationalism', 'steam and print', 'coexistence' and 'genocide'. ${ }^{8}$ For us, then, the age of rogues is less a temporality than a genre of politics that very much emerged out of these entangled historical processes. As Alan Mikhail and Christine Philliou have noted, 'identifying particular ages with their own characteristics, features, and cultural attributes' has a further benefit of 'suspending the question of outcomes' and evaluates a period on its own terms.' We believe this is all the more necessary in late Ottoman historiography,

${ }^{5}$ Uğur Ümit Üngör, Paramilitarism: Mass Violence in the Shadow of the State (Oxford: Oxford University Press, 2020), 6-18.

${ }^{6}$ Andreas Wimmer and Nina Glick Schiller, 'Methodological Nationalism and Beyond: Nation-State Building, Migration and the Social Sciences', Global Networks 2(4) (2002): 301-34.

7 Helge Jordheim, 'Against Periodization: Koselleck's Theory of Multiple Temporalities', History and Theory 51(2) (2012): 151-71.

${ }^{8}$ Eric Hobsbawm, The Age of Empire, 1875-1914 (New York: Vintage, 1989); Francis Robinson (ed.), Cambridge History of Islam: The Islamic World in the Age of Western Dominance (Cambridge: Cambridge University Press, 2010); M. Brett Wilson, Translating the Qur'an in an Age of Nationalism: Print Culture and Modern Islam in Turkey (Oxford: Oxford University Press, 2014); James L. Gelvin and Nile Green (eds), Global Muslims in the Age of Steam and Print (Berkeley, CA: University of California Press, 2014); Ussama S. Makdisi, Age of Coexistence: The Ecumenical Frame and the Making of the Modern Arab World (Oakland, CA: University of California Press, 2019).

9 Alan Mikhail and Christine M. Philliou, 'The Ottoman Empire and the Imperial Turn', Comparative Studies in Society and History 54(4) (2012): 721-45, 731. 
where the benefit of hindsight continues to stand at the heart of historical meta-narratives. ${ }^{10}$

As a collective endeavour, Age of Rogues hopes to attend to this task by mapping out the connected history of transgressive actors and their shared political culture that survived the First World War, even if their empires did not. In this sense, this volume is a study of a generation, covering roughly the formative period of an adult's lifespan from the late nineteenth century to the mid-interwar years. We suggest that this was a time marked by similar, if not shared, experiences of contentious sociability as it unfolded across the connected geography of the Balkans, the Middle East and the Caucasus. As such, while chapters in this volume focus foremost on the Ottoman world, they provide a range of biographical and prosopographical studies that are rooted in imperial frontiers - contributions that are particularly attentive to the experiences of non-Muslim communities, questions of gender and agents of emerging social classes. ${ }^{11}$

Perhaps most critically, this volume is transregional in its outlook. ${ }^{12}$ After

${ }^{10}$ For our own interventions against the teleological bias in Ottoman Studies, see Alp Yenen, 'Envisioning Turco-Arab Co-Existence between Empire and Nationalism', Die Welt des Islams 61(1) (2021): 72-112; Ramazan Hakkı Öztan, 'Point of No Return? Prospects of Empire after the Ottoman Defeat in the Balkan Wars (1912-1913)', International Journal of Middle East Studies 50(1) (2018): 65-84; Ramazan Hakkı Öztan, 'Nationalism in Function: "Rebellions" in the Ottoman Empire and Narratives in its Absence', in M. Hakan Yavuz and Feroz Ahmad (eds), War and Collapse: World War I and the Ottoman State (Salt Lake City: University of Utah Press, 2016), 161-202.

${ }^{11}$ In this sense, we situate our work in a burgeoning line of biographical and prosopographic approaches to contentious actors in the Ottoman Empire and the Middle East. See Michael Provence, The Last Ottoman Generation and the Making of the Modern Middle East (Cambridge: Cambridge University Press, 2017); Laila Parsons, The Commander: Fawzi alQawuqji and the Fight for Arab Independence, 1914-1948 (New York: Hill \& Wang, 2016); Benjamin C. Fortna, The Circassian: A Life of Esref Bey, Late Ottoman Insurgent and Special Agent (Oxford: Oxford University Press, 2016).

${ }^{12}$ This connected geography roughly corresponds to what Karl Kaser coined as 'Eurasia Minor' (Kleineurasien), a region connecting the Balkans to the Black Sea littoral, and the Middle East to the Caucasus. Karl Kaser, The Balkans and the Near East: Introduction to a Shared History (Münster: LIT-Verlag, 2011). For other transregional approaches that centre around the Ottoman world, see Stefan Rohdewald, Stephan Conermann and Albrecht Fuess (eds), Transottomanica-osteuropäisch-osmanisch-persische Mobilitätsdynamiken: Perspektiven und Forschungsstand (Göttingen: V\&R Unipress, 2019); Steffen Wippel and Andrea FischerTahir (eds), Jenseits etablierter Meta-Geographien: Der Nahe Osten und Nordafrika in tran- 
all, when it comes to the study of war, violence and revolution, historians have often chosen to highlight regional exceptionalism. We hope to depart from such emphasis on distinct paths of regional development and therefore challenge the compartmentalisation of history by area studies. Inspired by the existing body of literature that explore Ottoman legacies in post-imperial spaces, Age of Rogues hopes to suggest shared trajectories of historical development across what many believe to be distinct regions. ${ }^{13}$ In studying the Balkans, the Middle East and the Caucasus in an interactive framework, the volume ultimately seeks to point to commonalities in historical development, and highlight opportunities to study a cross-regional, if not a global history of transgressive politics.

We consider the connected regions of the Balkans, the Middle East and the Caucasus as frontiers of empires. In framing this vast geography as a frontier, we take both multilateral and unilateral dimensions into consideration. In their multilateral dimensions, frontiers correspond to what have been variously called 'shatterzones' and 'borderlands' of empires. ${ }^{14}$ In the unilateral sense of the concept, frontiers are as much the sites of heightened

sregionaler Perspektive (Baden-Baden: Nomos, 2018); Pascal Firges, Tobias Graf, Christian Roth and Gülay Tulasoğlu (eds), Well-Connected Domains: Towards an Entangled Ottoman History (Leiden: Brill, 2014).

${ }^{13}$ For studies of the shared Ottoman legacy in the Balkans and the Middle East, see Carl L. Brown (ed.), Imperial Legacy: The Ottoman Imprint on the Balkans and the Middle East (New York: Columbia University Press, 1996); Christine Philliou, 'Paradox of Perceptions: Interpreting the Ottoman Past through the National Present', Middle Eastern Studies 44(5) (2008): 661-75; Edin Hajdarpašić, 'Out of the Ruins of the Ottoman Empire: Reflections on the Ottoman Legacy in South-Eastern Europe', Middle Eastern Studies 44(5) (2008): 715-34; Eyal Ginio and Karl Kaser (eds), Ottoman Legacies in the Contemporary Mediterranean: The Balkans and the Middle East Compared (Jerusalem: European Forum at the Hebrew University, 2013). Frederick Anscombe offers a similar shared history of the Balkans and the Middle East in his State, Faith, and Nation in Ottoman and Post-Ottoman Lands (Cambridge: Cambridge University Press, 2014).

${ }^{14}$ Omer Bartov and Eric D. Weitz (eds), Shatterzone of Empires: Coexistence and Violence in the German, Habsburg, Russian, and Ottoman Borderlands (Bloomington: Indiana University Press, 2013); Alfred J. Rieber, The Struggle for the Eurasian Borderlands: From the Rise of Early Modern Empires to the End of the First World War (Cambridge: Cambridge University Press, 2014). 
civilisational and colonial encounters ${ }^{15}$ as they are the peripheries subordinated to state formation and centralisation. ${ }^{16}$ In the Ottoman Empire, much like elsewhere, these dimensions of frontiers were intricately linked to one another. Heightened competition in inter-imperial frontiers in the late nineteenth century, for example, drove state centralisation and civilisational missions in the empire's internal frontiers, ${ }^{17}$ as 'the state needed the frontier . . while the frontier might not have needed the state'. ${ }^{18}$ At other times, the empire's internal frontiers turned inter-imperial, as was the case with Eastern Anatolia during the First World War or the Ottoman frontiers in North Africa. ${ }^{19}$

Taken as a whole, Ottoman frontiers had long been spaces of contention no matter which trajectory they followed. In these seemingly peripheral settings, contentious episodes, as dictated by inter-imperial competition and elite rivalries as well as demographic changes, ${ }^{20}$ created local economies of

15 Imperial and colonial encounters between the Muslim world and European empires is discussed in its regional and imperial varieties in David Motadel (ed.), Islam and the European Empires (Oxford: Oxford University Press, 2014).

${ }^{16}$ One cannot overestimate the impact of centre-periphery approaches in Ottoman Studies. For a paradigmatic essay, see Şerif Mardin, 'Center-Periphery: A Key to Turkish Politics', Daedalus 102 (1973): 169-90. While scholars of the early modern period stressed the break-up of the centre-periphery alliance, such as in Rifa'at Ali Abou-El-Haj, Formation of the Modern State: The Ottoman Empire Sixteenth to Eighteenth Centuries (Albany, NY: State University of New York Press, 1991), historians of the modern period studied the bargaining of power between the Istanbul and provincial power-holders. For a critique of centreperiphery approaches, see Cem Emrence, Remapping the Ottoman Middle East: Modernity, Imperial Bureaucracy, and the Islamic State (London: I. B. Tauris, 2011).

${ }_{17}$ Ussama Makdisi, 'Ottoman Orientalism', American Historical Review 107(3) (2002): 768-96; Selim Deringil, “"They Live in a State of Nomadism and Savagery”: The Late Ottoman Empire and the Post-Colonial Debate', Comparative Studies in Society and History 45(2) (2003): 311-42; Thomas Kühn, 'Shaping and Reshaping Colonial Ottomanism: Contesting Boundaries of Difference and Integration in Ottoman Yemen, 1872-1919', Comparative Studies of South Asia, Africa and the Middle East 27(2) (2007): 313-29.

${ }^{18}$ Eugene L. Rogan, Frontiers of the State in the Late Ottoman Empire: Transjordan, 1850 1921 (Cambridge: Cambridge University Press, 1999), 9.

${ }^{19}$ Michael A. Reynolds, Shattering Empires: The Clash and Collapse of the Ottoman and Russian Empires 1908-1918 (Cambridge: Cambridge University Press, 2011); Mostafa Minawi, The Ottoman Scramble for Africa: Empire and Diplomacy in the Sahara and the Hijaz (Stanford, CA: Stanford University Press, 2016).

${ }^{20}$ Jack A. Goldstone, Revolution and Rebellion in the Early Modern World: Population Change 
competitive violence which led to the emergence of contentious politics. As many historians have illustrated time and again, this dynamic has been the primary feature of the contested borderlands of the Ottoman Empire since the late eighteenth century. ${ }^{21}$ Yet, only from the second half of the nineteenth century onwards, we argue, did the existing local repertoires of contention what one may call traditional cultures of transgression - begin to adopt global models and turn into forms that could be adopted and mimicked in frontier struggles elsewhere. ${ }^{22}$ Particularly after the first wave of globalisation started diffusing actors, ideas, tools and repertoires, as we point out, rogues began to emerge in frontiers where the local struggles could become part of the global, and the global might connect with the local. ${ }^{23}$ These globalising processes not only enabled cooperation among transgressive actors, but also helped them to see their struggle as part of a wider script of contention that had been taking place on a more global scale. ${ }^{24}$

and State Breakdown in England, France, Turkey, and China, 1600-1850, 25th anniversary edn (New York: Routledge, 2016).

${ }^{21}$ See various contributions in A. C. S. Peacock (ed.), The Frontiers of the Ottoman World (Oxford: Oxford University Press, 2009). See also Khaled Fahmy, All the Pashas Men: Mehmed Ali, His Army, and the Making of Modern Egypt (Cairo: American University in Cairo Press, 2002); Isa Blumi, Rethinking the Late Ottoman Empire: A Comparative Social and Political History of Albania and Yemen 1878-1918 (Istanbul: Isis Press, 2003); Ali Yaycioglu, Partners of the Empire: The Crisis of the Ottoman Order in the Age of Revolutions (Stanford, CA: Stanford University Press, 2016). How Iran's tribal frontiers shaped state formation is discussed in Firoozeh Kashani-Sabet, Frontier Fictions: Shaping the Iranian Nation, 1804-1946 (Princeton, NJ: Princeton University Press, 1999); Stephanie Cronin, Tribal Politics in Iran: Rural Conflict and the New State, 1921-1941 (London: Routledge, 2007); Arash Khazeni, Tribes and Empire on the Margins of Nineteenth-Century Iran (Seattle: University of Washington Press, 2009).

${ }^{22}$ For repertoires of contention, see Charles Tilly, From Mobilization to Revolution (Reading: Addison-Wesley, 1978), 151-9. Different types of repertoires and regimes commonly shape each other. Charles Tilly, Contentious Performances (Cambridge: Cambridge University Press, 2008), 146-74.

${ }^{23}$ For the most recent examples of this line of approach, see Houssine Alloul, Edhem Eldem and Henk de Smaele (eds), To Kill a Sultan: A Transnational History of the Attempt on Abdülhamid II (1905) (London: Palgrave Macmillan, 2018); Houri Berberian, Roving Revolutionaries: Armenians and the Connected Revolutions in the Russian, Iranian, and Ottoman Worlds (Oakland, CA: University of California Press, 2019).

${ }^{24}$ This is best studied in global comparisons and connections of the constitutional revolutions in the early twentieth century. Nader Sohrabi, 'Historicizing Revolutions: Constitutional 
This chapter will introduce the age of rogues as a framework for studying transgressive politics at the frontiers of the Ottoman Empire. The first section will first zoom in on the turn-of-the-century Ottoman frontier in Macedonia, a historical theatre of charged interstate competition and local rivalries that gave birth to a particular brand of rogue actors. Second, by intersecting the history of the Macedonian revolutionary organisations in the early twentieth century with the biography of İsmail Enver, a prominent Ottoman counterinsurgency officer who would later become a Young Turk revolutionary, we will seek to illustrate the individual trajectory of a rogue between forces of revolution and empire. Third, by building on the example of Macedonians and Young Turks, we will explain the historical sociology of transgressive politics that led to the emergence of an age of rogues at the frontier of empires. Finally, we will stress the need to study the culture of agency that defines the historical trajectory of transgressive politics at the frontiers of the Ottoman Empire.

\section{A Frontier of Contention: Ottoman Macedonia, 1878-1908}

The Balkans has long been a frontier among empires. ${ }^{25}$ Since the European age of revolutions, the region had encountered its own wave of revolts and crises. ${ }^{26}$ But only by the end of the nineteenth century did Ottoman Macedonia emerge as one of the most contentious inter-imperial frontiers in world history. ${ }^{27}$ By then, the region had become such a theatre of heightened levels of

Revolutions in the Ottoman Empire, Iran, and Russia, 1905-1908', American Journal of Sociology 100(6) (1995): 1383-447; Charles Kurzman, Democracy Denied, 1905-1915: Intellectuals and the Fate of Democracy (Cambridge, MA: Harvard University Press, 2008); Erik Jan Zürcher, 'The Young Turk Revolution: Comparisons and Connections', Middle Eastern Studies 55(4) (2019): 481-98.

25 The region most notably functioned as the military frontier (Militärgrenze) between the Habsburgs and the Ottomans. See Jean Nouzille, Histoire de frontières: l'Autriche et l'Empire ottoman (Paris: Berg, 1991). For a recent revisiting of the military frontier, see the contributions for the forum 'The Habsburg-Ottoman Borderlands: New Insights for the Study of the Nineteenth-Century European Legal and Social Order' in Austrian History Yearbook 51 (2020): 15-87.

${ }^{26}$ Frederick F. Anscombe, 'The Balkan Revolutionary Age', Journal of Modern History 84(3) (2012): 572-606.

${ }^{27}$ While there was no such administrative unit in the empire as Macedonia, the term referred to a geography that corresponded to the Ottoman provinces of Salonica, Bitola and Kosovo, 
political competition that it made a contemporary conclude that Macedonia was 'a conveniently elastic term which is made to include all the territory anyone wishes to annex'. ${ }^{28}$ The remark was not far off the mark, capturing the essence of what came to be known in diplomatic circles as the 'Macedonian question', which had developed since the end of the Russo-Ottoman War 1877-1878. ${ }^{29}$ This was when the sweeping Russian gains alarmed Britain, France and Austria-Hungary, who convened the Congress of Berlin (1878) to check the Russian influence in the Balkans. ${ }^{30}$ While it restored the balance of power, the Treaty of Berlin projected the protection of minority rights in the newly independent post-Ottoman states, ensuring not only the rights of Jews and Christians, but also the continued involvement of the Great Powers in affairs of the Balkan frontier for decades to come. ${ }^{31}$

The treaty resulted in the independence of Montenegro, Romania and

situated in southeastern Europe. Yet what Macedonia is and who Macedonians are is a debate that continues to spark nationalist tensions in the Balkans to this day. See Hugh Poulton, Who Are the Macedonians? (Bloomington: Indiana University Press. 1995); Loring M. Danforth, The Macedonian Conflict: Ethnic Nationalism in a Transnational World (Princeton, NJ: Princeton University Press, 1995); James Pettifer, The New Macedonian Question (New York: St Martin's Press, 1999); Victor Roudometof, Collective Memory, National Identity and Ethnic Conflict: Greece, Bulgaria and the Macedonian Question (Westport, CT: Praeger, 2002); Basil C. Gounaris, 'Macedonian Questions', Southeast European and Black Sea Studies 2(3) (2002): 63-94. For a recent take on how the naming dispute was resolved, see Matthew Nimetz, 'The Macedonian "Name" Dispute: The Macedonian Question - Resolved?' Nationalities Papers 48(2) (2020): 205-14. Yet this seemingly narrow conflict on naming rights is indicative of the broader relevance of the past for the politics of the present - an aspect that is well studied in the critical Balkan historiographies, such as in Keith Brown, The Past in Question: Modern Macedonia and the Uncertainties of Nation (Princeton. NJ: Princeton University Press, 2003); Roumen Daskalov, The Making of a Nation in the Balkans: Historiography of the Bulgarian Revival (Budapest: Central European University Press, 2004).

${ }^{28}$ Mary Edith Durham, The Burden of the Balkans (London: Edward Arnold, 1905), 58.

${ }^{29}$ Fikret Adanır, Die Makedonische Frage: Ihre Entstehung und Entwicklung bis 1908 (Wiesbaden: Steiner, 1979).

${ }^{30}$ M. Hakan Yavuz and Peter Sluglett (eds), War and Diplomacy: The Russo-Turkish War of 1877-1878 and the Treaty of Berlin (Salt Lake City: University of Utah Press, 2011).

${ }^{31}$ Carole Fink, Defending the Rights of Others: The Great Powers, the Jews, and International Minority Protection, 1878-1938 (Cambridge: Cambridge University Press, 2004). For a critical take on minority rights treaties, see Laura Robson, 'Capitulations Redux: The Imperial Genealogy of the post-WWI "Minority” Regimes', American Historical Review, forthcoming. 
Serbia, as well as the granting of autonomy to Bulgaria. The sultan's remaining territories in Europe, on the other hand, were gradually to turn into a zone of competition among these newly emerging neighbouring states and an already independent Greece, as each of them sought to cultivate irredentist aspirations and conflicting visions of cultural, religious and economic influence over Ottoman Macedonia. The region had long been home to an ethno-religiously mixed population, with a majority of Orthodox Christians comprising Bulgarians, Greeks, Serbs, Macedonians and Vlachs, as well as sizeable communities of Turkish and Albanian Muslims, and Jews. Their socio-economic cleavages would become the major currency with which the growing interstate competition was to unfold. ${ }^{32}$ Initially, the contours of this competition followed the script inherited from the previous decade. Bulgaria and Serbia sought to increase the influence of their national churches vis-àvis the Greek Patriarchate, while also establishing schools in order to appeal to the minds and hearts of Ottoman Macedonians whom they saw as copatriots. ${ }^{33}$ Revolutionary tactics did exist, but they largely remained under state control.

The status quo changed after 1885 when a secret committee of revolutionaries in Plovdiv, with links to Sofia, took control of the autonomous province of Eastern Rumelia and announced its unification with Bulgaria. Ottoman armies were mobilised and Greece threatened to annex parts of Macedonia, while the Great Powers cautioned restraint. Serbia acted on its fury and declared war, but Bulgaria emerged victorious against all odds. ${ }^{34}$ A crucial consequence of the episode was the souring of relations between Russia and Bulgaria, due to the latter's increasing autonomy of action. ${ }^{35}$ While St Petersburg's plots would thicken in the following years to bring

${ }^{32}$ For an excellent intervention in this regard, see Basil C. Gounaris, 'Social Cleavages and National "Awakening" in Ottoman Macedonia', East European Quarterly 29(4) (1996): 409-26.

33 Dimitris Stamatopoulos, 'The Bulgarian Schism Revisited', Modern Greek Studies Yearbook 24/25 (2008/2009), 105-25; Dimitris Stamatopoulos, 'Orthodox Ecumenicity and the Bulgarian Schism', Etudes Balkaniques 51(1) (2015): 70-86.

${ }^{34}$ Gül Tokay, 'A Reassessment of the Macedonian Question, 1878-1908', in H. Yavuz and Peter Sluglett (eds), War and Diplomacy: Russo-Turkish War and Berlin Treaty (Salt Lake City: University of Utah Press, 2011), 253-69.

35 R. J. Crampton, Bulgaria (Oxford: Oxford University Press, 2007), 123-32. 
Bulgaria back to its orbit, the Russian withdrawal of support ultimately created a wedge between moderate and revolutionary factions in Bulgaria: as the Bulgarian prime minister Stefan Stambolov moved closer to the sultan and embraced a more restrained policy towards Macedonia, he came to estrange the revolutionary elements that had been thus far acting within the parameters defined by Sofia. ${ }^{36}$ Organisations, such as the Young Macedonian Literary Society, were shut down and Macedonian students were kicked out of schools due to ongoing purges of 'Russophiles'. Among those forced to leave for Macedonia were individuals such as Dame Gruev, Georgi Delchev and Ivan Hadzhinikolov who met in 1893 in Salonica, where they established the Internal Macedonian Revolutionary Organisation (IMRO hereafter), which would ultimately become the model for rogue conduct in the Ottoman world. ${ }^{37}$

If the earlier generation of Bulgarian revolutionaries was denied access to the metropole - that is, Constantinople ${ }^{38}$ - this newer generation of revolutionaries was barred from accessing national politics in Sofia. ${ }^{39}$ Stambolov's bid to set Bulgaria on a course independent from Russia and the ensuing crackdowns swelled the ranks of the estranged. Soon after its inception, IMRO quickly began to expand its organisation through a string of secret cells across the region, calling for a Macedonia that was autonomous both from Constantinople and Sofia. ${ }^{40}$ In doing so, they implemented circulating notions of revolutionary activism on the ground, which they saw as embodied

${ }^{36}$ For a biography of Stambolov, see Duncan M. Perry, Stefan Stambolov and the Emergence of Modern Bulgaria, 1870-1895 (Durham, NC: Duke University Press, 1993).

37 Duncan M. Perry, The Politics of Terror: The Macedonian Liberation Movements 1893-1903 (Durham, NC: Duke University Press, 1988), 35-7.

${ }^{38}$ For an overview of those schooled in Istanbul, see Orlin Sabev, 'Boğazici Kıyılarında Hayata Hazırlanmak: Osmanlı Istanbul'unda Okumuş Bulgarlar Üzerine Bazı Gözlemler', in Feridun M. Emecen, Emrah Safa Gürkan and Ali Akyıldız (eds), Osmanl Istanbulu III. Uluslararası Osmanlı Istanbulu Sempozyumu Bildirileri (Istanbul: Istanbul 29 Mays Üniversitesi Yayınları, 2015), 163-81.

${ }^{39}$ In arguing as such, we are particularly drawing upon Benedict Anderson's discussion of official nationalism and the prevented passages of creole elites to positions of power in the metropole. Benedict Anderson, Imagined Communities: Reflections on the Origin and Spread of Nationalism (London: Verso, 2006).

${ }^{40}$ Stephen Fischer-Galati, 'The Internal Macedonian Revolutionary Organization: Its Significance in "Wars of National Liberation”', East European Quarterly 6(4) (1973): 458-9. 
in the person of Vasil Levski, who was a legendary revolutionary before being caught and hanged by the Ottoman authorities in $1873 .{ }^{41}$ While the IMRO drew from a shared repertoire of action available across the Balkans in general and Bulgaria in particular, it continued to be cautious of external meddling although remaining open to external support for the cause. After the Supreme Macedonian Committee was founded in Sofia in 1895 - an organisation that would always be its arch rival, the IMRO developed relations with it, on the condition of keeping its own organisational independence, so that it could reach out to the Macedonian constituency in Sofia. ${ }^{42}$

By the end of the century, the IMRO boasted of an underground organisation, complete with its own postal system and experienced couriers and smugglers who disseminated money, weapons and propaganda to its members, while also ensuring communication among the leadership - all in all operating as a state within a state. ${ }^{43}$ IMRO leaders travelled regularly across Macedonia to maintain the organisational networks, while local leaders - often teachers - tapped into local student bodies to expand membership. As Keith Brown noted, 'resistance to Ottoman rule was far more labor-intensive and economically integrated than national mythologies sometimes suggest'. ${ }^{44}$ In line with the larger goal of preparing the groundwork for a peasant rebellion, the organisation propagated a message

${ }^{41}$ Vasil Levski's activities are often seen as the harbinger of the April Uprising of 1876. For a narrative of his activities, see the records of his interrogation by the Ottoman authorities, Cengiz Yolcu, “'Bulgar Fesad Komitesi Reisi” Vasil Levski'nin Eylemleri ve Mahkemede Verdiği İfade Üzerine bir Değerlendirme', Güney-Doğu Avrupa Araştırmaları Dergisi 27 (2015): 15-63. For later appropriations of Levski's legacy, see Maria Todorova, Bones of Contention: The Living Archive of Vasil Levski and the Making of Bulgaria's National Hero (Budapest: Central European University Press, 2009).

42 Perry, The Politics of Terror, 47-9, 82-3.

43 Frederick Moore, 'The Macedonian Committees and the Insurrection', in Luigi Villlari (ed.), The Balkan Question: The Present Condition of the Balkans and of European Responsibilities (London: John Murray, 1905), 192.

${ }^{44}$ See Keith Brown, Loyal unto Death: Trust and Terror in Revolutionary Macedonia (Bloomington: Indiana University Press, 2013), 54. For an overview of these emigration patterns, see Basil C. Gounaris, 'Emigration from Macedonia in the Early Twentieth Century', Journal of Modern Greek Studies 7(1) (1989): 133-53. For global and local interactions of Ottoman migration flows, see Isa Blumi, Ottoman Refugees, 1878-1939: Migration in a Post-Imperial World (London: Bloomsbury, 2013). 
of radical land reform to a receptive audience of impoverished peasants, promising a radical re-ordering of rural society by overthrowing Muslim landowners. ${ }^{45}$ The organisation similarly tapped into circuits of seasonal labour migration. Aware of the latter possibility, the Ottoman authorities kept a close tap on labour market dynamics, particularly attentive to inexplicable patterns in seasonal labour movement, as seemingly happened in the spring of $1903 .^{46}$

For the IMRO, the use of violence initially served similar goals of organisational empowerment. When resorted to for strategic aims, violent acts served to achieve discipline among ranks, eliminate rivals and raise money, while also helping to consolidate popular support by highlighting the IMRO's commitment to the cause. ${ }^{47}$ In this sense, local revolutionary committees and armed bands not only set an example of dedication, but also played an active role in drilling the peasants in how to use weapons and engage in guerrilla warfare. They even used visual aids to describe how to use bayonets, revolvers, scythes and bombs, illustrating different ways to shoot in different postures while taking cover behind trees and fences against an approaching enemy. ${ }^{48}$ Even if the use of violence against enemies was glorified, the organisation knew the limits of its capabilities, particularly vis-à-vis regular units. From 1897 onwards, however, as Ottoman authorities slowly understood the full scale of the organisation's webs of loyalty and acted to dismantle it, the IMRO was forced to ramp up its coercive capacity and increase the number of its paramilitary bands. In principle, choosing leaders and recruiting members for each band was less of a problem than arming them. But the end of the century also saw a greater availability of second-hand weapons and hand

45 Tasos Kostopoulos, "Land to the Tiller": On the Neglected Agrarian Component of the Macedonian Revolutionary Movement, 1893-1912', Turkish Historical Review 7(2) (2016): 134-66.

46 Başbakanlık Osmanlı Arşivi (Prime Ministry's Ottoman Archives, BOA hereafter), DH. TMIK. M. 140-22, lef 1, 3 and 6. This particular intelligence originated from the Third Army Headquarters in Salonica and supported by the Ministry of Public Security, but was later dismissed by the authorities.

47 İpek K. Yosmaoğlu, Blood Ties: Religion, Violence, and the Politics of Nationhood in Ottoman Macedonia, 1878-1908 (Ithaca, NY: Cornell University Press, 2014), 209-87.

${ }^{48}$ For such visual aids intercepted by the revolutionaries, see BOA. Y.MTV. 228-37, 2 Nisan 318. 
bombs in the world markets, which slowly trickled into the hands of IMRO bands. ${ }^{49}$

The Ottoman Empire already maintained a significant military presence in the region, but the emerging demands of rural guerrilla warfare soon led to the creation of specific units that were led by officers handpicked from among the most skilful of their class from imperial staff colleges. Despite up-to-date staff education, better equipment and numerical strength, the Ottoman counterinsurgency operations remained precarious until 1905. In the end, guerrilla warfare demanded swift responses, but the Ottoman command structure did not always process intelligence fast enough to enable its units to pursue the bands. ${ }^{50}$ Even when they could, Ottoman officers were trained in conventional warfare, not in guerrilla tactics. Lacking an officially articulated strategy, the officers learned counterinsurgency methods only through experience on the field. ${ }^{51}$ It did not help, either, that the Ottoman officer corps was divided between the mektepli (schooled) and alaylı (commissioned) officers, which ultimately caused significant infighting that held back coordinated action. ${ }^{52}$

The IMRO was plagued by similar problems which, however, had broader consequences for Ottoman Macedonia. Particularly after the Salonica Affair in 1901 when most members of its central committee were arrested by the authorities, a considerable power vacuum emerged, which raised the stakes

49 Ramazan Hakkı Öztan, 'Tools of Revolution: Global Military Surplus, Arms Dealers, and Smugglers in the Late Ottoman Balkans, 1878-1908', Past \& Present 237(1) (2017): 16795; Ramazan Hakkı Öztan, 'Commodities of Nationalism: Technologies of Rebellion and Networks of Resistance in the Late Ottoman Balkans, 1878-1912', PhD thesis, University of Utah, 2016.

${ }^{50}$ Gül Tokay, 'The Macedonian Question and the Origins of the Young Turk Revolution, 1903-1908', PhD thesis, University of London, 1994, 147-53.

${ }^{51}$ Mesut Uyar and Edward J. Erickson, A Military History of the Ottomans: From Osman to Atatürk (Santa Barbara, CA: Praeger, 2009), 215-16. This lack of familiarity with guerrilla warfare was not peculiar to the Ottomans. For an account of the French troubles in Algeria, see Douglas Porch, 'Bugeaud, Galliéni, Lyautey: The Development of French Colonial Warfare', in Peter Paret (ed.), Makers of Modern Strategy from Machiavelli to the Nuclear Age (Princeton, NJ: Princeton University Press, 1986), 376-407.

52 While the 'schooled' designated those who became officers after a modern military education, the latter meant those who rose through the ranks thanks to their loyalty to the sultan. Feroz Ahmad, Turkey: The Quest for Identity (Oxford: Oneworld, 2003), 76. 
considerably in leadership cadres. As Adria Lawrence argued, 'when and where nationalist movements fractured, nationalist actors had incentives to adopt violent strategies to compete with one another' ${ }^{53}$ Indeed, different factions operating in this increasingly competitive environment quickly began 'to outbid each other by the adoption of more radical positions or the use of more militant forms of action'. ${ }^{54}$ Right after the Salonica arrests in 1901, the Supreme Committee in Sofia tried to take over the internal organisation - a bid that ultimately failed. A year later in 1902, the Supremacists raised the banner of revolt and sent their own chetas to lead the revolution in Macedonia before the IMRO could - a strategy frustrated by Ottoman units. In late 1902, Ivan Garvanov, who now controlled IMRO, responded by convening a makeshift congress which then announced the long-awaited peasant uprising to take place in spring $1903 .{ }^{55}$ Meanwhile, a splinter, anarchist group called the Gemidzhii, with loose links both to the Supremacists and the IMRO, responded by carrying out bomb attacks in Salonica, targeting many Western-owned ships, cafes, banks and schools to attract global attention to the plight of Macedonians. ${ }^{56}$

These cycles of competitive escalation resulted in the Ilinden Uprising, which was the only episode of open rebellion in Ottoman Macedonia that featured the participation of around 20,000 armed rebels. The Porte responded by mobilising forces that, according to one estimate, equalled those during the Russo-Ottoman War in $1877-8 . .^{57}$ The confrontation lasted from August well into the autumn and led to a death toll of thousands, while Ottoman counterinsurgency tactics rendered tens of thousands of local subjects into refugees. The uprising not only failed to attract foreign intervention, but also fractured the IMRO into multiple factions that would continue to

${ }^{53}$ Adria Lawrence, 'Triggering Nationalist Violence: Competition and Conflict in Uprisings against Colonial Rule', International Security 35(2) (2010): 90.

${ }^{54}$ Donatella della Porta, 'Radicalization: A Relational Perspective', Annual Review of Political Science 21 (2018): 465.

55 Nadine Lange-Akhund, The Macedonian Question, 1893-1908 from Western Sources (New York: Columbia University Press, 1998), 107-18.

${ }^{56}$ Pınar Şenışık, 'Osmanlı Makedonyası'nda Şiddet ve Nisan 1903 Olayları', Türkiyat Mecmuası 27(1) (2017): 289-303.

57 The National Archives (TNA), Foreign Office (FO), 78/5268/521, Therapia, 28 August 1903, f. 286. 
compete for leadership in Macedonia, often in violent ways. ${ }^{58}$ The situation became worse when Greece and Serbia, and to a much lesser extent Romania, responded to the 1903 uprising by forming and sending their own armed bands into Macedonia in a bid to protect the interests of those they saw as copatriots. ${ }^{59}$ According to this logic of competitive violence, 'every thrust had to be answered with counter-thrust, and passivity was a sign of weakness, not wisdom' ${ }^{60}$ The Ilinden Uprising had therefore turned Ottoman Macedonia into a frontier of rogues, where interstate competition and intra-elite rivalries began to unfold in more violent ways than ever before.

As violence engulfed Macedonia, the Ottoman security forces ramped up their counterinsurgency efforts. The Ottoman officers who took part in these operations were themselves politically alienated by the authoritarian rule of Sultan Abdülhamid II. Faced with revolutionaries in Macedonia, the empire's counterinsurgents were about to go rogue. In this sense, they displayed a political development that was similar to that of the IMRO. While the leaders of the latter were in one way or another tied to the Bulgarian high school in Salonica, the Ottoman revolutionaries were graduates of Ottoman military and medical academies in Istanbul. The origin of these Ottoman revolutionary committees went back to a secret society founded in 1889 by four students at the military school for medicine, but they and their growing supporters were soon exiled by the Hamidian regime in $1895 .{ }^{61}$ These so-called 'Young Turk' émigrés were united under the Committee of Union and Progress (Ittihad ve Terakki Cemiyeti, CUP hereafter) and formed the

${ }^{58}$ Ryan Gingeras, 'The Internal Macedonian Revolutionary Organization: "Oriental" Terrorism, Counterinsurgency, and the End of the Ottoman Empire', in Carola Dietze and Claudia Verhoeven (eds), The Oxford Handbook of the History of Terrorism (Oxford: Oxford University Press, 2014).

59 Douglas Dakin, The Greek Struggle in Macedonia, 1897-1913 (Thessaloniki: Institute for Balkan Studies, 1966); Dimitris Livanios, "Conquering the Souls": Nationalism and Greek Guerilla Warfare in Ottoman Macedonia, 1904-1908', Byzantine and Modern Greek Studies 23(1) (1999): 195-221.

${ }^{60}$ Mark Mazower, Salonica, City of Ghosts: Christians, Muslims and Jews, 1430-1950 (New York: Alfred A. Knopf, 2005), 253.

${ }^{61}$ M. Şükrü Hanioğlu, The Young Turks in Opposition (Oxford: Oxford University Press, 1995); Oya Gözel-Durmaz, 'The Rise of the Ottoman Military Medical School as the Centre of Anti-Hamidian Opposition', in Oya Gözel-Durmaz, Abidin Çevik, and Günay Gönüllü (eds), Current Debates in History and Politics (London: IJOPEC, 2017), 7-20. 
backbone of the external committees that were established in Europe, notably in Paris, Brussels and Geneva (but also in Cairo and Tripoli).

Like the IMRO, the Young Turk movement broke into factions, largely due to disagreements over tactics and the means of revolution, but also because of personal rivalries. Ultimately, however, it was the dynamics of the competitive escalation of violence in Macedonia after 1903 that gave the upper hand to the 'activist' faction among the Young Turks which was based in Salonica. ${ }^{62}$ Many of them had built a professional military career in counterinsurgency operations. For them, Macedonia was not only a source of existential anxiety for the viability of the Ottoman Empire, but also a laboratory where they were socialised in the tactics of conspiratorial politics and revolutionary warfare. ${ }^{63}$ Without doubt, as Erik Jan Zürcher aptly noted, the Young Turks were the 'children of the borderlands'.$^{64}$ One of them was İsmail Enver, a young Ottoman military officer serving in the Third Army, who would have a spectacular trajectory in this age of rogues.

\section{A Rogue between Revolution and Empire: İsmail Enver, 1881-1922}

The frontier had long been important in shaping Enver's identity and worldview. Although he was born in Istanbul in 1881, Enver was a descendant of refugees from Crimea who were relocated to the Ottoman Empire after the Russian conquest. ${ }^{65}$ Young Enver spent his school years in Bitola in

${ }^{62}$ This coming to power of the 'activist' faction is one of the main arguments of M. Şükrü Hanioglu, Preparation for a Revolution: The Young Turks, 1902-1908 (Oxford: Oxford University Press, 2001). For a further discussion, see also Suavi Aydın, 'İki İttihatTerakki. İki Ayrı Zihniyet, İki Ayrı Siyaset', in Tanıl Bora and Murat Gültekingil (eds), Modern Türkiye'de Siyasi Düşünce I: Cumburiyet'e Devreden Düsünce Mirasi: Tanzimat ve Meşrutiyet'in Birikimi (Istanbul: İletişim Yayınları, 2004), 117-28.

${ }^{63}$ The centrality of Macedonian experience to the emergence of Young Turks has long been noted by a number of Turkish scholars, most notably Zafer Tarık Tunaya, Türkiye'de Siyasal Partiler, Vol. 3: İttihat ve Terakki: Bir Çağın, Bir Kuşă̆ın, Bir Partinin Tarihi (Istanbul: Hürriyet Vakf1 Yayınları, 1989). On the impact of the Macedonian question on the Young Turks, see Adanır, Die Makedonische Frage; Tokay, 'The Macedonian Question and the Origins of the Young Turk Revolution'; Mehmet Hacısalihoğlu, Die Jungtürken und die Mazedonische Frage (1850-1918) (Munich: Oldenbourg, 2003).

${ }^{64}$ Erik Jan Zürcher, 'The Young Turks - Children of the Borderlands', International Journal of Turkish Studies 9(1/2) (2003), 275-86.

${ }^{65}$ For Enver's biographies, see Murat Bardakçı, Enver (Istanbul: İş Bankası Yayınları, 2015); 
Ottoman Macedonia, where his father served as an agricultural technician for the provincial bureaucracy. Having graduated from the Hamidian institutions of education in Macedonia, Enver enrolled at the military academy in Istanbul. Like many of his peers who received modern education, Enver, too, considered himself both a patriot and a progressive. Enver's hero in his youth was Ali Süavi (1839-78), a revolutionary of the former generation and the origin of Enver's later nom de guerre as a revolutionary. ${ }^{66}$ Ali Süavi was one of the leading members of the 'Young Ottomans', an opposition movement founded in 1865 as a secret society of civil servants, but he was later killed while carrying out a coup attempt against Abdülhamid in 1878, after the latter had prorogued the constitution of $1876 .{ }^{67}$

Although invested in subversive political thoughts, with ready role models in front of him, young Enver had no organic connection to the CUP. Only after being arrested and interrogated by the Hamidian secret police did Enver become irreversibly embittered towards the regime's despotism. ${ }^{68}$ After graduating from the staff college as the second in his class, Enver was assigned to the Bitola garrison of the Third Army to take part in the counterinsurgency operations in unruly Macedonia (Figure 1.1). Only a few months into his new post in the summer of 1903, Enver witnessed at first hand the Ilinden uprising and the power of revolutionary warfare. In an autobiographical sketch about his counterinsurgency experience in Macedonia, Enver noted that 'the Internal Macedonian [Revolutionary] Committee reminded him of the reserve military structure of the Ottoman army'. As he declared with envy, the Macedonian committee was recruiting young men far more efficiently than the Ottoman army. The IMRO not only mirrored the organisation of the Ottoman army, but also the Ottoman state.

M. Şükrü Hanioğlu, 'Enver Paşa', Türkiye Diyanet Vakfi İslam Ansiklopedisi, 44 vols (Istanbul: Türkiye Diyanet Vakfı İslam Araştırmaları Merkezi, 1988-2013), 11:261-4; Şevket Süreyya Aydemir, Enver Paşa: Makedonya'dan Orta Asya'ya, 3 vols (Istanbul: Remzi Kitabevi, 1972). There is still no comprehensive biography of Enver in English.

${ }^{66}$ Bardakçı, Enver, 72.

${ }^{67}$ Florian Riedler, Opposition and Legitimacy in the Ottoman Empire: Conspiracies and Political Cultures (London: Routledge, 2011), 26-70.

68 This episode is recounted in Glen W. Swanson, 'Enver Pasha: The Formative Years', Middle Eastern Studies 16(3) (1980): 194-5. 
'Everybody knew that in Macedonia', Enver wrote, 'there was a state within a state' which undermined the Ottoman state's own infrastructure while building up its own parallel networks. ${ }^{69}$ While mobilising devoted supporters and training capable leaders, as Enver wrote in his memoirs, 'this Organisation had a cadre of young idealists, fearless volunteers, who were willing to give up their lives'. For Enver, these were a new type of political partisans who were shaping the course of events. These so-called komitadjis 'were cruel and ready for bloody sacrifice', conducting terrorist attacks and robberies and bringing out into the open the Ottoman state's inability to dispense justice. ${ }^{70}$ 'Was it possible to establish law and order?' Or, more precisely, Enver wondered, 'how could the Sultan's Empire survive?'71 The contemporary revolutionary wave in Russia and Persia after the Japanese victory of 1905 incited not only restive Ottoman-Muslim officers in Macedonia, like Enver, but also the wider the Young Turk movement in exile to turn to revolution in order to save the empire. ${ }^{72}$

In 1906, Enver was recruited by the Ottoman Liberty Society, a 'Young Turk' secret society of officers and bureaucrats in Salonika. 'We had studied other revolutions', said Enver, while 'I myself had studied very closely the Internal Organization of the Macedonian Bulgars. I admired it, and it gave us many hints. ${ }^{73}$ By 1907 , the Ottoman Liberty Society in Macedonia merged with the Committee of Union and Progress in Parisian exile. After the merger, the CUP ended up formally adopting the organisational structure

${ }^{69}$ Here quoted from the English translation in Christ Anastasoff, 'Enver Pasha's Comments on the Work and Organization of the Macedonian Anti-Ottoman Committees', Balkania: An International Quarterly Magazine on Balkan Affairs 7(1) (1973): 3-8. These autobiographical sketches were penned in 1909 and were first published in Aydemir, Enver Paşa: Makedonya'dan Orta Asya'ya. For the full text in Turkish transliteration, please consult Halil E. Cengiz (ed.), Enver Paşa'nın Anıları: (1881-1908) (Istanbul: İletişim Yayınları, 1991).

${ }^{70}$ Anastasoff, 'Enver Pasha's Comments', 6.

${ }^{71}$ Ibid., 7.

${ }^{72}$ Nader Sohrabi, 'Global Waves, Local Actors: What the Young Turks Knew About Other Revolutions and Why It Mattered', Comparative Studies in Society and History 44(1) (2002): 45-79. See also Nader Sohrabi, Revolution and Constitutionalism in the Ottoman Empire and Iran (Cambridge: Cambridge University Press, 2011), 82-4.

${ }^{73}$ Quoted from an interview with Enver in Charles-Roden Buxton, Turkey in Revolution (London: T. Fisher Unwin, 1909), 135. 


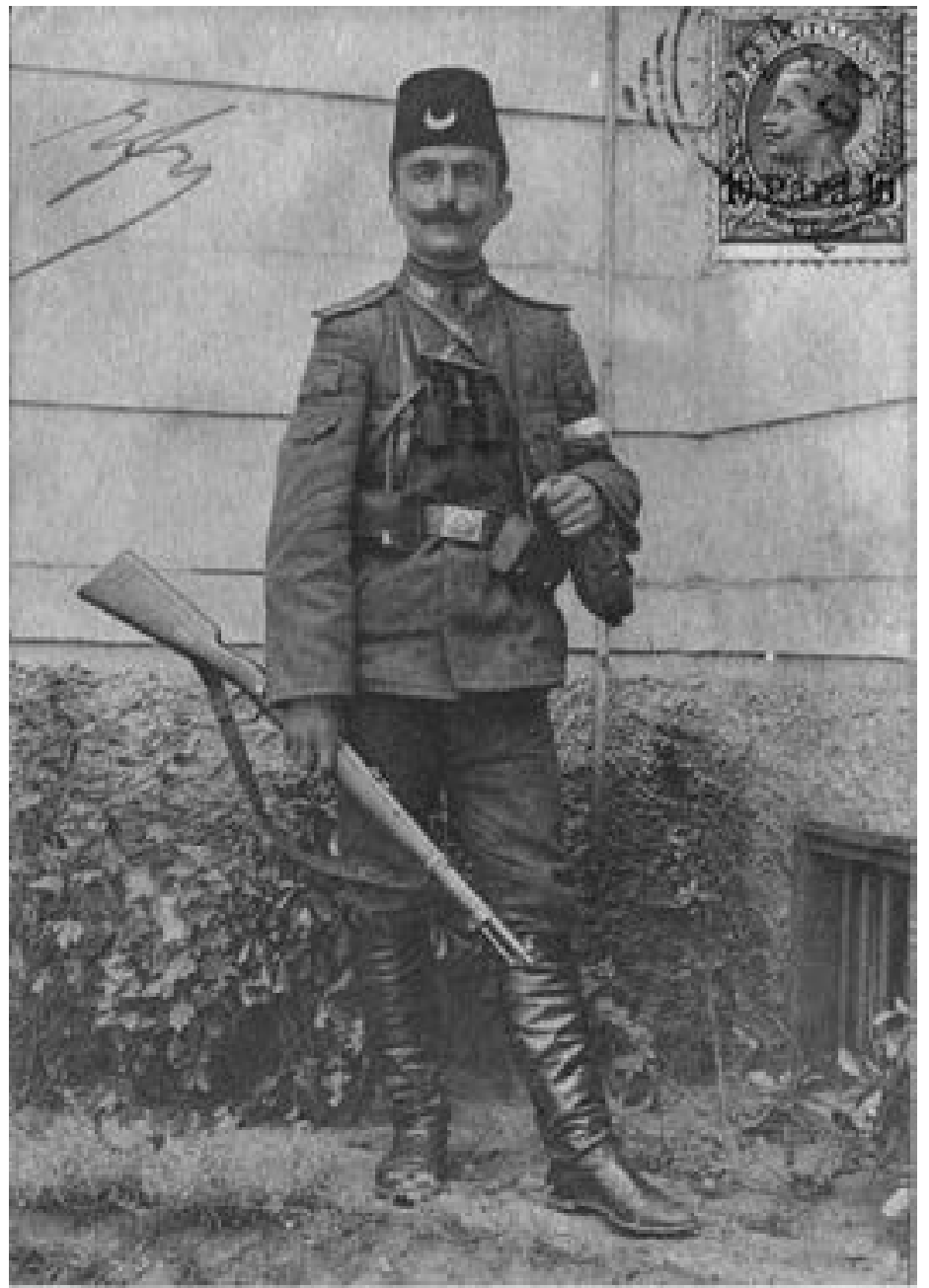

Le champion de la titerte, Enver Bey en tenoe de campagne

Figure 1.1 Enver Bey as a counterinsurgency officer in Ottoman Macedonia, 1903-8. See at: https://commons.wikimedia.org/wiki/File:Enver_Pasha_Ottoman_ Postcard.jpg.

and revolutionary tactics of the Macedonian revolutionaries. ${ }^{74}$ While the 48th article of the internal regulations of the CUP required that 'all members

${ }^{74}$ Hanioğlu, Preparation for a Revolution, 210-27. 
who join the committee should sacrifice their lives for the sacred cause of the committee', there was a volunteer unit of 'those members who wish to be enlisted as self-sacrificing volunteers' (feda' $i$ ) for special operations. ${ }^{75}$ The CUP adopted a statue of armed forces for the coordination of revolutionary mobilisation and the organisation of Muslim-nationalist armed vigilantism vis-à-vis Balkan revolutionaries. ${ }^{76}$

While Balkan revolutionaries provided an organisational model, Great Power interventions in Macedonia provided the backdrop to the CUP's revolutionary plans. ${ }^{77}$ The Reval meeting (Tallinn in Estonia) between British King Edward VII and Russian Tsar Nicholas II in June 1908, where the Macedonian question was expected to be settled, created an immediate urgency for revolutionary action. ${ }^{78}$ Following the executive orders of the CUP, secret committee members in the Third Army, most prominently Enver, took to mountains and started a mutiny that combined guerrilla tactics with popular mobilisation among the Muslim villages. ${ }^{79}$ Once an unrelated Albanian uprising in Firzovik (today Ferizaj/Uroševac in Kosovo) was co-opted by the revolutionaries by performing a collective oath, the picture of an organised mass uprising in the name of constitutionalism was complete. ${ }^{80}$ The extent

75 Quoted in ibid., 217.

${ }^{76}$ Cengiz, Enver Paşa'nın Anıları, 111-13.

77 Gül Tokay, 'Macedonian Reforms and Muslim Opposition during the Hamidian Era: 1878-1908', Islam and Christian-Muslim Relations 14(1) (2010): 51-65; Murat Kaya, 'Western Interventions and Formation of the Young Turks' Siege Mentality', Middle East Critique 23(2) (2014): 127-45. However, it remains doubtful how far previous tax revolts in Anatolia were part of the revolutionary moment, as argued by Aykut Kansu, The Revolution of 1908 in Turkey (Leiden: Brill, 1997).

${ }^{78}$ For an overview of the events and historiographical debates, see Erik Jan Zürcher, 'The Historiography of the Constitutional Revolution: Broad Consensus, Some Disagreement and a Missed Opportunity', in The Young Turk Legacy and Nation Building: From the Ottoman Empire to Atatürk's Turkey (London: I. B. Tauris, 2010), 26-40. For the revolutionary processes in the Macedonian and Albanian provinces, see Hanioğlu, Preparation for a Revolution, 261-78; Hacısalihoğlu, Jungtürken und die Mazedonische Frage, 162-205; George W. Gawrych, The Crescent and the Eagle: Ottoman Rule Islam and the Albanians 1874-1913 (London: I. B. Tauris, 2006), 140-69; Isa Blumi, Reinstating the Ottomans: Alternative Balkan Modernities, 1800-1912 (Basingstoke: Palgrave Macmillan, 2011), $146-8$.

79 Cengiz, Enver Paşa'nın Anıları, 86-125.

${ }^{80}$ Gawrych, Crescent and the Eagle, 151-2. 
of the uprising was multiplied by the flood of telegrams sent to the palace from various places in Ottoman Macedonia and elsewhere. Encouraged by the developments, the revolutionaries threatened to march to the capital in order to reinstate the constitution of 1876 . Fearing further chaos, Sultan Abdülhamid announced the restoration of the constitution on 24 July, which marked the Ottoman constitutional revolution of 1908.

Enver's post-revolutionary career continued to draw from his Macedonian culture of revolution. After the revolution, Macedonian and other Balkan komitadjis returned to towns and villages, where they were welcomed by the crowds. Enver was publicly celebrated as the 'hero of freedom'. The revolution brought certain types of transgressive actors into the fold of conventional politics. ${ }^{81}$ Despite forming an official political party, the CUP remained a secret revolutionary committee in the footsteps of the Macedonian tradition. ${ }^{82}$ While elbowing themselves a place in the capital, several committee leaders, including Enver, continued to associate themselves with Albanian bandits, irregular fighters and urban gangsters. In the following years, the CUP would accordingly instrumentalise its 'guerrilla spirit' to maintain its firm grip on political affairs, while also engineering consent through more formal avenues of politics. ${ }^{83}$

Even though Enver was promoted to the prestigious post of a military attaché in Berlin, he returned to guerrilla warfare after Italy occupied Ottoman Libya in 1911. Along with a special envoy of volunteers, Enver secretly travelled to Benghazi where he conducted skirmishes with local militias against Italian forces and strongholds. ${ }^{84}$ As such, the Balkan-style irregular warfare was transported to North Africa and merged there with the existing local forms of tribal resistance. Rushed back to the Balkans in the midst of

${ }^{81}$ Sohrabi, Revolution and Constitutionalism, 24. But the dreams of an inclusive revolution were soon to be shattered. See Bedross der Matossian, Shattered Dreams of Revolution: From Liberty to Violence in the Late Ottoman Empire (Stanford, CA: Stanford University Press, 2014).

${ }^{82}$ Tunaya, Türkiye'de Siyasal Partiler, 3:13.

${ }^{83}$ On the 'guerrilla spirit' of the CUP, see George W. Gawrych, 'The Culture and Politics of Violence in Turkish Society, 1903-14', Middle Eastern Studies 22(3) (1986): 320. See also Sohrabi, Revolution and Constitutionalism, 135-88.

${ }^{84}$ For Enver's diary entries from this period, see Enver Pascha, Um Tripolis, ed. Friedrich Perzyński (Munich: Bruckmann, 1918). 
the First Balkan War, Enver and fellow Young Turks were devastated by the terrible defeat and blamed the government, which had previously ousted the CUP from political offices. Enver, with the help of a group of CUP gunmen, engineered a violent coup in Istanbul, where the minister of war was killed and the government was forced to resign. In the Second Balkan War, Enver recaptured the former Ottoman capital of Edirne in a theatrical manner, adding yet another token to his official heroisation. ${ }^{85}$ The CUP increasingly established a single-party dictatorship in the Ottoman Empire from then onwards. Already married to an Ottoman princess, Enver became the minister of war and the generalissimo, endowed with the title of Paşa at the onset of the First World War. ${ }^{86}$ His meteoric rise was not a simple result of growing militarism in the Ottoman Empire but, instead, a manifestation of the CUP's growing transgressive capacities, in which Enver and his entourage proved to be influential in creating facts on the ground. ${ }^{87}$

The Ottoman war effort in the First World War was accompanied by revolutionary and paramilitary mobilisation on all frontiers, including a declaration of a jihad against the Sultan-Caliph's 'infidel' enemies at home and abroad.$^{88}$ For the purposes of unconventional warfare, Enver organised special

${ }^{85}$ Eyal Ginio, Ottoman Culture of Defeat: The Balkan Wars and their Aftermath (Oxford: Oxford University Press, 2015), 227-64.

${ }^{86}$ On Enver's role and how much he represented the weltanschauung of his Young Turk generation on the eve of the First World War, see Mustafa Aksakal, The Ottoman Road to War in 1914: The Ottoman Empire and the First World War (Cambridge: Cambridge University Press, 2008).

${ }^{87}$ There is a tendency in the historiography to overstate role of the military in Young Turk politics, such as in otherwise rich studies, see Handan Nezir-Akmeşe, The Birth of Modern Turkey: The Ottoman Military and the March to World War I (London: I. B. Tauris, 2005); M. Naim Turfan, Rise of the Young Turks: Politics, the Military, and Ottoman Collapse (London: I. B. Tauris, 2000). Despite the importance of the military, the CUP remained the dominant political force after 1913; see Erik Jan Zürcher, 'Young Turk Governance in the Ottoman Empire during the First World War', Middle Eastern Studies 55(6) (2019): 897-913; M. Şükrü Hanioğlu, 'Civil-Military Relations in the Second Constitutional Period, 1908-1918', Turkish Studies 12(2) (2011): 177-89.

${ }^{88}$ There is now a growing body of literature on the Ottoman experience in the First World War. For general overviews, see Ryan Gingeras, Fall of the Sultanate: The Great War and the End of the Ottoman Empire, 1908-1922 (Oxford: Oxford University Press, 2016); Eugene L. Rogan, The Fall of the Ottomans: The Great War in the Middle East (New York: Basic Books, 2015). On military mobilisation, see Yiğit Akın, When the War Came Home: The 
forces and secret intelligence operations under the Ottoman army's Teşkilat-ı Mahsusa ('Special Organisation'), which intersected with the CUP's own clandestine paramilitary bands. ${ }^{89}$ At the most tragic intersection of imperial and revolutionary struggles was the 'Armenian question'. In the eyes of the CUP leadership, the Macedonian question was about to repeat itself in Anatolia. ${ }^{90}$ Armenian homelands were located at the frontier of empires and were the sites of heightened inter-imperial competition and revolutionary rivalries. ${ }^{91}$

Before officially declaring war against Russia on the German side, the CUP made a secret offer to the Armenian Revolutionary Federation (ARF hereafter), with whom they had long had good relations until the recent Armenian reform talks. ${ }^{92}$ '[I]f war breaks out, rebellion in the Caucasus is inevitable: highlanders [Dagestanis], Turks and the Georgians alike will stand up, let the Armenians join them', as CUP emissaries proposed to the ARF. 'In

Ottomans' Great War and the Devastation of an Empire (Stanford, CA: Stanford University Press, 2018); Mehmet Beşikçi, The Ottoman Mobilization of Manpower in the First World War: Between Voluntarism and Resistance (Leiden: Brill, 2012). On the Ottoman jihad, see Erik Jan Zürcher (ed.), Jihad and Islam in World War I: Studies on the Ottoman Jihad at the Centenary of Snouck Hurgronje's 'Holy war Made in Germany' (Leiden: Leiden University Press, 2015).

${ }^{89}$ On the contentious historiography of the Teşkilat-ı Mahsusa, see Polat Safi, 'History in the Trench: The Ottoman Special Organization - Teşkilat-1 Mahsusa Literature', Middle Eastern Studies 48(1) (2012): 89-106. For the organisational history of the Teşkilat-ı Mahsusa, see Polat Safi, 'The Ottoman Special Organization - Teşkilat-1 Mahsusa: An Inquiry into Its Operational and Administrative Characteristics', PhD thesis, Bilkent University, 2012. The historiography of the Teşkilat-ı Mahsusa is primarily complicated by the question of whether it participated in the Armenian massacres and whether it was under the command of the Ottoman army or the CUP after March 1915. See Ahmet Tetik, Teşkilat-ı Mahsusa (Umur-ı Şarkıyye Dairesi) Tarihi, 2 vols (Istanbul: Türkiye İş Bankası Kültür Yayınları, 2014-18); Oktay Özel, 'Tehcir ve Teşkilat-ı Mahsusa', in Fikret Adanır and Oktay Özel (eds), 1915: Siyaset, Tehcir, Soykırm (Istanbul: Tarih Vakfi Yurt Yayınları, 2015), 377-407; Taner Akçam, 'When Was the Decision to Annihilate the Armenians Taken?' Journal of Genocide Research 21(4) (2019), 457-80.

${ }^{90}$ Erik Jan Zürcher, 'Macedonians in Anatolia: The Importance of the Macedonian Roots of the Unionists for their Policies in Anatolia after 1914', Middle Eastern Studies 50(6) (2014): 960-75.

${ }^{91}$ Onur Önol, The Tsar's Armenians: A Minority in Late Imperial Russia (London: I. B. Tauris, 2017); Reynolds, Shattering Empires, 46-81.

92 Dikran Mesrob Kaligian, Armenian Organization and Ideology under Ottoman Rule: 1908 1914 (New Brunswick, NJ: Transaction Publishers, 2009). 
return we promise to give Armenians autonomy. ${ }^{\prime 93}$ Uncertain about the prospects of a war against Russia, however, Armenian revolutionaries rejected and decided to remain neutral in a war of empires. ${ }^{94}$ Some other local Armenian committees prepared for armed defence and resistance, creating yet further suspicions in the paranoid eyes of state surveillance. ${ }^{95}$ Even more, the formation of Armenian volunteer battalions in the Russian army connected the Armenian revolutionaries directly with the inter-imperial competition. ${ }^{96}$ After the devastating defeat in the Caucasus campaign in the winter of 1914/15, which he had commanded personally, Enver put the blame on subversive activities of Armenians in Eastern Anatolia. ${ }^{97}$ Insisting that the Armenian population constituted a danger, he demanded from Talat Paşa that the ministry of the interior should deport Armenians from the conflict region to the Syrian desert. The rationale of counterinsurgency aside, however, the forced deportations were accompanied by political purges, paramilitary massacres, the abduction of women and children, as well as economic confiscations that ultimately had genocidal consequences for the Armenian population of Anatolia. Indeed, the convolution of imperial and revolutionary struggles was dramatically decisive in the destruction of the Ottoman commonwealth - the CUP leaders certainly knew what they were doing. ${ }^{98}$

Much like Eastern Anatolia, the Arab frontier was also plagued by imperial

${ }^{93}$ Quoted in Yektan Türkyılmaz, 'Rethinking Genocide: Violence and Victimhood in Eastern Anatolia, 1913-1915', PhD thesis, Duke University, 2011, 160. See also Kaligian, Armenian Organization and Ideology, 220.

94 Türkyılmaz, 'Rethinking Genocide', 163-4.

${ }^{95}$ Donald Bloxham, 'Terrorism and Imperial Decline: The Ottoman-Armenian Case', European Review of History 14(3) (2007): 301-24.

${ }_{96}$ Armenian volunteer battalions were soon demobilised by the Russians, precisely because of their anti-imperialist revolutionary motivation. Manoug Joseph Somakian, Empires in Conflict: Armenia and the Great Powers, 1895-1920 (London: I. B. Tauris, 1995), 109.

${ }_{97}$ The evidence does not necessarily back up Enver's conclusion that there was a widescale Armenian revolt. Taner Akçam, The Young Turks' Crime against Humanity: The Armenian Genocide and Ethnic Cleansing in the Ottoman Empire (Princeton, NJ: Princeton University Press, 2012), 162-75; Edward J. Erickson, Ottomans and Armenians: A Study in Counterinsurgency (New York: Palgrave, 2013), 161-82.

98 Taner Akçam, 'When Was the Decision'; Ümit Kurt, 'Theatres of Violence on the Ottoman Periphery: Exploring the Local Roots of Genocidal Policies in Antep', Journal of Genocide Research 20:3 (2018): 351-71. 
competition and revolutionary rivalries that had significant consequences for the region's populations. Although the CUP regime had invested great efforts into its Arab provinces after the Balkan defeat, their despotic centralisation policies were responsible for the continued discourse of Turkification among the Arab elites. ${ }^{99}$ Arab secret societies became more revolutionary with the outbreak of the First World War, even though most of them opted more for decentralism and federalism than separatism. ${ }^{100}$ In early 1916, Enver made an official inspection tour to Syria, Palestine, Sinai and the Hijaz. A few months later, Cemal Paşa, the CUP's man on the ground, publicly executed a prominent group of Arab nationalists for alleged revolutionary conspiracy in May 1916, as Enver and other CUP leaders had given him a free hand against subversive Arab activities. ${ }^{101}$ Although the British-sponsored Arab Revolt in Hijaz in the summer of 1916 was not a direct cause of these events, it certainly ended up increasing revolutionary rivalries and changed the course of the inter-imperial war in the Middle East.

In the end, the Ottomans lost the war. Having conquered Baku shortly before the Ottoman defeat, Enver briefly considered leading an insurgency from Eastern Anatolia and the Caucasus, where weapons were stacked and troops were deployed. A senior German official, however, advised him against becoming a 'brigand chief' out of desperation. ${ }^{102}$ Vocal critiques of the CUP, too, were demanding that 'rogue and false attempts such as the Special Organization as well as the detrimental activities of secret and vicious committees should come to an end'. ${ }^{103}$ Despite all the advice and critique, Enver

99 Hasan Kayal, Arabs and Young Turks: Ottomanism, Arabism, and Islamism in the Ottoman Empire, 1908-1918 (Berkeley, CA: University of California Press, 1997), 209-10; Leila Tarazi Fawaz, A Land of Aching Hearts: The Middle East in the Great War (Cambridge, MA: Harvard University Press, 2014), 251-2.

100 Eliezer Tauber, 'Secrecy in Early Arab Nationalist Organizations', Middle Eastern Studies 33(1) (1997): 119-27; Yenen, 'Envisioning Turco-Arab Co-Existence', 95-102.

${ }^{101}$ M. Talha Çiçek, War and State Formation in Syria: Cemal Pasha's Governorate during World War I, 1914-17 (London: Routledge, 2014), 45.

${ }^{102}$ Hans von Seeckt, letter (Constantinople) to Dorothee von Seeckt (Germany), 20 October 1918, Bundesarchiv Militärarchiv (German Federal Archives - Military Archive, BA-MA), Freiburg im Breisgau, N247/218, 173.

${ }^{103}$ Cenab Şehabeddin, 'Cihad', Hadisat, 4 November 1918, quoted in Orhan Koloğlu, Aydınlarımızın Bunalım Yilı 1918: Zaferi Nihai'den Tam Teslimiyete (Istanbul: Boyut Kitaplar, 2000), 108. 
decided to go rogue anyway. He and his fellow CUP leaders fled to Germany as political outcasts and internationally wanted war criminals, while the CUP's intact underground networks started to organise the armed resistance movement against the Allied occupation. ${ }^{104}$ As a professional revolutionary promising to incite anti-colonial uprisings in the Muslim world, Enver was welcomed by Bolshevik leaders in Soviet Russia in August 1920 and founded the Union of Muslim Revolutionary Societies. ${ }^{105}$ Similar to his revolutionary actions in Macedonia, Enver planned in detail how local revolutionary committees in Muslim lands should entertain their 'revolutionary militia organisation' against European empires. ${ }^{106}$ After all, the whole world seemed to have resembled Macedonia in the aftermath of the First World War.

While Enver refashioned himself as a global rogue, his local supporters in Trabzon, a CUP stronghold on the Black Sea coast, had established what an intelligence officer from Ankara dismissively called 'a state within a state'. ${ }^{107}$ After a failed bid for power in Anatolia in September 1921, however, Enver decided to seek his fortunes elsewhere and joined the Basmachi rebels in Turkestan. But his stint in Central Asia did not last long, as he was killed in a charge against the Red Army. 'Que voulez-vous, c'est la fin d'un révolutionnaire!' commented a fellow Young Turk to a German friend upon hearing that Enver had been killed in action. ${ }^{108}$ Indeed, Enver's political trajectory from his Machiavellian rise as a revolutionary officer and his Macbethian transformation into an imperial generalissimo to his Quixotic fall as a professional revolutionary illustrates the complexities that characterise his transgressive agency. Even if his trajectory was most spectacular, we argue that

${ }^{104}$ Erik Jan Zürcher, The Unionist Factor: The Role of the Committee of Union and Progress in the Turkish National Movement, 1905-1926 (Leiden: Brill, 1984); Nur Bilge Criss, Istanbul under Allied Occupation, 1918-1923 (Leiden: Brill, 1999), 94-114.

${ }^{105}$ Alp Yenen, 'The Young Turk Aftermath: Making Sense of Transnational Contentious Politics at the End of the Ottoman Empire, 1918-1922', PhD thesis, University of Basel, 2016, published online 2019), at: https://doi.org/10.5451/unibas-007110817.

106 Enver Pasha, 'Draft of the Revolutionary Organization of Autonomous Committees', n.d., Türk Tarih Kurumu Arşivi (Archive of the Turkish Historical Society, TTK), Enver Pasha Papers, 03-09.

107 Feridun Kandemir, Şehit Enver Paşa Türkistan'da (Istanbul: Barıman Yayınevi, 1945), 76.

108 Hans von Seeckt, 'Erinnerungen an Enver Pascha: Von Generaloberst von Seeckt', Velhagen \& Klasings Monatshefte 45(1) (1931): 84. 
Enver was not a singular example but, in fact, the manifestation of a new type of an actor who, like many other similar rogues of his time, emerged out of the contentious frontiers of empires and prevailed against rival rogues to have a say in the brutal making of a new political order. ${ }^{109}$

\section{Transgressive Politics in a Changing World}

In order to better understand rogues like Enver and organisations such as the IMRO, we need to contextualise under what conditions transgressive politics actually emerge. As an analytical category, we accordingly locate transgressive politics at the intersections of three distinct spheres of politics. First, the very notion of transgression necessitates the framing of conventional politics as routine and formal political conduct. According to Weberian political sociology, conventional politics are state-centric, whereby states are the only legitimate actors that could define the conventions of politics. Second, if we are to assume that politics have conventions, every collective claim that attempts to challenge these conventions must be considered as a contention, if not a transgression. Therefore, our understanding of transgressive politics shares a common ground with contentious politics, which refers to a variety of collective political interactions from non-violent and episodic demonstrations to violent and prolonged insurgencies. ${ }^{110}$ While some contentious campaigns may collaborate with political institutions through conventional channels, other forms of contentious politics can become truly transgressive when contentious agency violates states' sovereignty or legitimacy. Third, transgressive politics can overlap with so-called parapolitics, particularly if

${ }^{109}$ Enver's trajectory is commonly read through ideological parameters. See, for instance: Şuhnaz Yılmaz, 'Revisiting Networks and Narratives: Enver Pasha's Pan-Islamic and PanTurkic Quest', in Odile Moreau and Stuart Schaar (eds), Subversives and Mavericks in the Muslim Mediterranean: A Subaltern History (Austin: University of Texas Press, 2016), 143-65.

${ }^{110}$ On the comparison of different types of contentious politics, see George Lawson, 'Reform, Rebellion, Civil War, Coup d'État and Revolution', in James Defronzo (ed.), Revolutionary Movements in World History: From 1750 to Present, 3 vols (Santa Barbara, CA: ABCCLIO, 2006), III:721; Jack A. Goldstone and Daniel P. Ritter, 'Revolution and Social Movements', in David A. Snow, Sarah A. Soule, Hanspeter Kriesi and Holly McCammon (eds), The WileyBlackwell Companion to Social Movements (New York: John Wiley, 2019), 683-97. 
they involve extra-legal (state) or illegal (non-state) agency as well as secretive structures of terrorism, paramilitarism and organised crime. ${ }^{111}$ We therefore locate rogue conduct at the transgressions of these three spheres, where agents and structures are involved in making violent and public actions to contend (or defend) the conventions of formal politics through extraordinary and extra-legal means (Figure 1.2).

If we are to follow neo-Weberian historical sociology as a historical process, modern state-formation was a result of 'protection rackets' that tried to monopolise the means of violence in establishing legitimate coercive power. ${ }^{112}$ In this sense, the origins of modern states can be traced back to institutions and actors that were involved in coercion, taxation and protection. Irregulars and mercenaries were as important in processes of state-formation across the frontiers as they were for conventional armies. ${ }^{113}$ Weber's sociology of the

${ }^{111}$ Robert Cribb, 'Introduction. Parapolitics, Shadow Governance and Criminal Sovereignty', in Eric Michael Wilson (ed.), Government of the Shadows: Parapolitics and Criminal Sovereignty (New York: Pluto Press, 2009), 1-9; Eric Michael Wilson, 'The Concept of the Parapolitical', in Eric Michael Wilson (ed.), The Dual State: Parapolitics, Carl Schmitt and the National Security Complex (Farnham: Ashgate, 2012), 1-28; Üngör, Paramilitarism, 64-182.

${ }^{112}$ Charles Tilly, 'War Making and State Making as Organized Crime', in Peter B. Evans, Dietrich Rueschemeyer and Theda Skocpol (eds), Bringing the State Back In (Cambridge: Cambridge University Press, 1985), 169-91; Charles Tilly, Coercion, Capital, and European States: AD 990-1990 (Cambridge, MA: Blackwell, 1990), 67-95. For a similarly 'bellicose' historical sociology of state-formation, see Michael Mann, Sources of Social Power, Vol. 1: A History of Power from the Beginning to A.D. 1760 (Cambridge: Cambridge University Press, 1986). For a discussion of bellicose theory of state-formation, see Siniša Malešević, The Sociology of War and Violence (Cambridge: Cambridge University Press, 2010), 71-5.

113 Tolga U. Esmer argues that irregulars are the byproduct of imperial governance, so much to the point that crime and governance cannot be distinguished from each other. Tolga U. Esmer, 'Economies of Violence, Banditry and Governance in the Ottoman Empire Around 1800', Past \& Present 224(1) (2014): 163-99. On the role of irregulars in stateformation, see Diane E. Davis, 'Contemporary Challenges and Historical Reflections on the Study of Militaries, States, and Politics', in Diane E. Davis and Anthony W. Pereira (eds), Irregular Armed Forces and Their Role in Politics and State Formation (Cambridge: Cambridge University Press, 2003), 3-34; Klejda Mulaj, 'Violent Non-State Actors: Exploring their State Relations, Legitimation, and Operationality', in Klejda Mulaj (ed.), Violent Non-State Actors in World Politics (London: Hurst, 2010), 1-25. At the same time, rivalling irregular bands also constituted a challenge to state-formation in the frontiers. Oren Barak and Chanan Cohen, "The "Modern Sherwood Forest": Theoretical and Practical Challenges', in Dan Miodownik and Oren Barak (eds), Nonstate Actors in Intrastate Conflicts (Philadelphia: University of Pennsylvania Press, 2013), 12-33. 


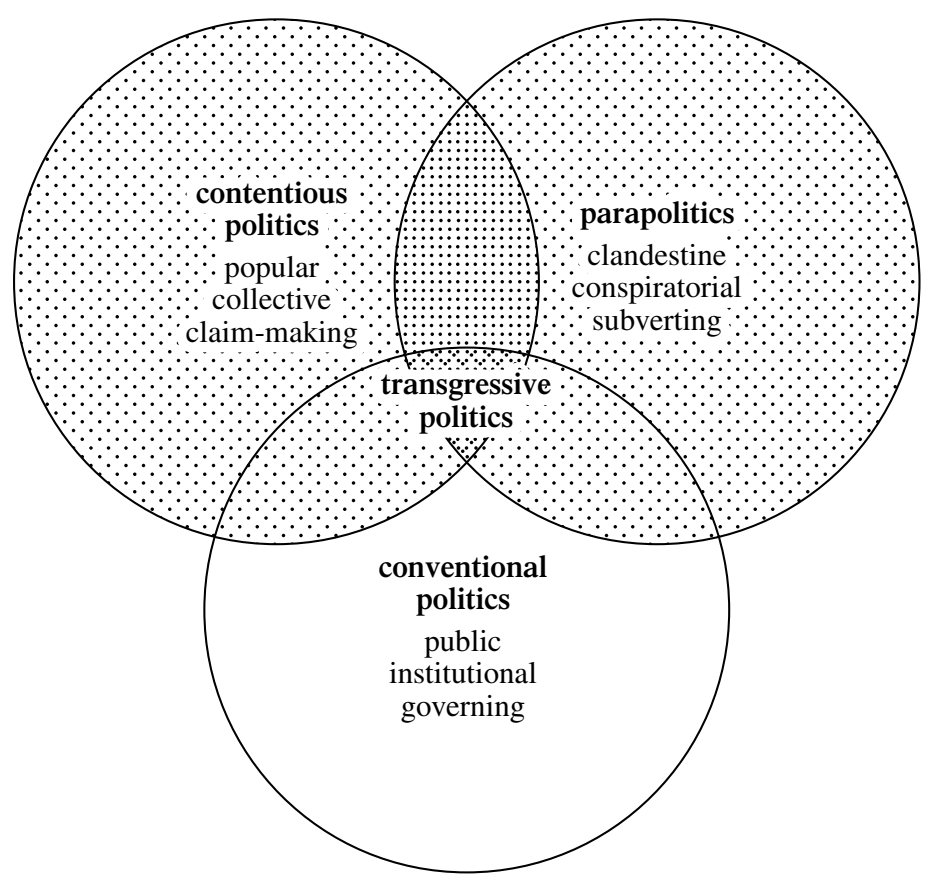

Figure 1.2 Locating transgressive politics.

state, which assumes that states are defined by the 'monopoly over legitimate means violence', ${ }^{114}$ is certainly less accurate in displaying the historical reality of imperial sovereignty. Empires effectively administer 'states of exception' on their frontiers and tolerate (if not delegate) the use of violence by others within a flexible legal framework. ${ }^{115}$ Both paramilitaries and partisans are

${ }^{114}$ Max Weber, Wirtschaft und Gesellschaft (Tübingen: Verlag von J.C.B. Mohr, 1922), 29. How far this monopoly is disregarded in imperial contexts is noted in Juan R. I. Cole, 'Of Crowds and Empires: Afro-Asian Riots and European Expansion, 1857-1882', in Fernando Coronil and Julie Skurski (eds), States of Violence (Ann Arbor: University of Michigan Press, 2006), 269-305, at 280; Tolga U. Esmer, 'Notes on a Scandal: Transregional Networks of Violence, Gossip, and Imperial Sovereignty in the Late Eighteenth-Century Ottoman Empire', Comparative Studies in Society and History 58(1) (2016): 127.

115 This idea that sovereignty is defined by the 'state of exception' comes from Carl Schmitt, Political Theology: Four Chapters on the Concept of Sovereignty (Chicago, IL: University of Chicago Press, 2005). In imperial contexts, this idea is discussed in Lauren Benton, $A$ Search for Sovereignty: Law and Geography in European Empires, 1400-1900 (Cambridge: Cambridge University Press, 2009), 279-99. 
transgressive agents who thrive in the state of exception and, in turn, define the contentious contours of state sovereignty on the ground. ${ }^{116}$

The Ottoman Empire is a case in point, as the use of irregulars and mercenaries in fact defined the very basis of its military and social power on the frontiers. ${ }^{117}$ The situation was similar on the other side of the Ottoman frontier, too, where the uskoks were the border raiders of the Habsburg Empire, protecting and violating the contentious frontier. ${ }^{118}$ Therefore, irregular warfare, by which we mean the decentralised organisation of small autonomous armed bands, was a formative element that sustained the autonomy of violence on imperial frontiers. As autonomous as rogues can be, however, some of them could be co-opted. In fact, empires regularly contracted such auxiliaries to perform state-sanctioned violence. ${ }^{119}$

The line between irregulars and mercenaries, as well as bandits and rebels, is a contentious matter of definition. The former two categorisations either depend on their eventual political trajectory or the length of service to the state, while the latter two are generally products of partisan representations. Most famously, however, Eric Hobsbawm coined the concept of social banditry by drawing attention to the example of the cult of banditry in the traditional cultures of the Balkans. Hobsbawm's social bandits were imagined as 'primitive rebels' who, due to their heroic subversion of the socio-economic coercion of the government,

116 Carl Schmitt's Theory of the Partisan (New York: Telos Press, 2007) should be understood in terms of 'state of exception'. See Gabriella Slomp, Carl Schmitt and the Politics of Hostility, Violence and Terror (Basingstoke: Palgrave Macmillan, 2009), 57-78; Wilson, 'The Concept of the Parapolitical'.

${ }^{117}$ For the use of irregulars (levends) by the Ottoman military, see Uyar and Erickson, $A$ Military History of the Ottomans, 91-4.

${ }^{118}$ Catherine Wendy Bracewell, The Uskoks of Senj: Piracy, Banditry, and Holy War in the Sixteenth-Century Adriatic (Ithaca, NY Cornell University Press, 1992).

119 Tolga U. Esmer, 'War, State and the Privatisation of Violence in the Ottoman Empire', in Robert Antony, Stuart Carroll and Caroline Dodds Pennock (eds), The Cambridge World History of Violence (Cambridge: Cambridge University Press, 2020), vol. 3, 194-216. Such lucrative imperial practices were continued by post-Ottoman nation-states in the Balkans, which came at the detriment of state institutions and civil society. See: John Gledhill and Charles King, 'Institutions, Violence, and Captive States in Balkan History', in Ottomans into Europeans: State and Institution-Building in South Eastern Europe, eds Wim Van Meurs and Alina Mungiu-Pippidi (London: Hurst, 2011), 245-76. 
supposedly received the support and admiration of the peasant populations. ${ }^{120}$ Despite his obvious romantic-socialist projection, there has indeed been a tradition in the Balkans, traceable in songs and epics that celebrate the legends of famous bandits - commonly known as hayduks in Hungarian and Slavic dialects or klephts in Greek - as heroes of the people. ${ }^{121}$ These traditional folkloric legends that celebrated hero-bandits ultimately informed nationalist (and later socialist) mythologies. ${ }^{122}$ As a category of transgressive politics and a phenomenon of social construction, social banditry can also be observed in the Middle East, but the rarity of local folkloric sources as well as the sectarian and tribal categories readily attached to the bandits tend to undermine attempts to frame them as such. ${ }^{123}$ After all, in colonial contexts, banditry not only needs to survive the violence of empires, but also their hegemony over the production of knowledge. ${ }^{124}$ As such, they are subjected both to discourses of defamation and heroisation, as was the case with the north Caucasian

${ }^{120}$ For Hobsbawm's social bandit definition, see Eric J. Hobsbawm, Primitive Rebels: Studies in Archaic Forms of Social Movement in the 19th and 20th Centuries, 3rd edn (Manchester: Manchester University Press, 1971), 13-29; Eric J. Hobsbawm, Bandits, rev. edn (New York: Pantheon, 1981), 17-29. The social banditry concept unleashed a vast research wave in various disciplines. For one early but major critique, see Anton Blok, 'The Peasant and the Brigand: Social Banditry Reconsidered', Comparative Studies in Society and History 14(4) (1972): 494-503.

${ }^{121}$ For critiques of idealised histories of social banditry in the Balkans, see Fikret Adanır, 'Heiduckentum und osmanische Herrschaft. Sozialgeschichtliche Aspekte der Diskussion um das frühneuzeitliche Räuberwesen in Südosteuropa', Südost-Forschungen 41 (1982): 43-116; Andreas Helmedach and Markus Koller, “"Haiducken” - Gewaltgemeinschaften im westlichem Balkanraum im 17. und 18. Jahrhundert', in Winfried Speitkamp (ed.), Gewaltgemeinschaften: Von der Spätantike bis ins 20. Jahrhundert (Göttingen: V\&R Unipress, 2013), 231-49.

${ }^{122}$ On the heroisation of bandits, see Alp Yenen, 'Banditen', in Ronald G. Asch, Achim Aurnhammer, Georg Feitscher and Anna Schreurs-Morét (eds), Compendium heroicum, issued by University of Freiburg, published online, 28 July 2020, at: https://dx.doi. org/10.6094/heroicum/bd1.0.20200728.

${ }^{123}$ For a comprehensive discussion, see Stephanie Cronin, 'Noble Robbers, Avengers and Entrepreneurs: Eric Hobsbawm and Banditry in Iran, the Middle East and North Africa', Middle Eastern Studies 52(5) (2016): 845-70.

${ }^{124}$ Kim A. Wagner, 'Thugee and Social Banditry Reconsidered', The Historical Journal 50(2) (2007): 353-76. See also Ranajit Guha, Elementary Aspects of Peasant Insurgency in Colonial India (Delhi: Oxford University Press, 1983). 
bandits (abrek) in the Russian Empire and thereafter. ${ }^{125}$ The latter-day trajectories of banditry in the Middle East are therefore indicative of how state-formation was accompanied by transgressive politics. The modern states in the region re-invented banditry as a social hazard in order to legitimise state control in distant peripheries. ${ }^{126}$ In Turkey, for instance, the continued rogue conduct of Kurdish bandits (eşkıyâ) until the 1960s illustrates the interplay between state centralisation and subaltern traditions of autonomous violence. ${ }^{127}$

While rogue conduct could inadvertently push governments to pursue coercion, respond through counterinsurgency tactics, and initiate coalitions among local and global enemies, rogues could also utilise and co-opt the very same technologies, tactics and coalitions to increase their own subversive capacities. For centuries, the Porte effectively co-opted warlords, bandits and rebels in governing its frontiers. ${ }^{128}$ From the late eighteenth century

125 Jeronim Perović, From Conquest to Deportation: The North Caucasus under Russian Rule (London: Hurst, 2018), 21-52; Rebecca Gould, Writers and Rebels: The Literature of Insurgency in the Caucasus (New Haven, CT: Yale University Press, 2016); Vladimir Bobrovnikov, 'Bandits and the State: Designing a "Traditional" Culture of Violence in the North Caucasus', in Jane Burbank, Mark Von Hagen, and Anatolyi Remnev (eds), Russian Empire: Space, People, Power 1700-1930 (Bloomington: Indiana University Press, 2007), 239-67.

126 Nathan Brown, 'Brigands and State Building: The Invention of Banditry in Modern Egypt', Comparative Studies in Society and History 32(2) (1990): 258-81.

127 Uğur Ümit Üngör, 'Rethinking the Violence of Pacification: State Formation and Bandits in Turkey, 1914-1937', Comparative Studies in Society and History 54(4) (2012): 746-69; Jordi Tejel Gorgas, "The Shared Political Production of "the East" as a "Resistant" Territory and Cultural Sphere in the Kemalist Era, 1923-1938', European Journal of Turkish Studies 10 (2009), at: http://journals.openedition.org/ejts/4064. For the continued occurrence of banditry in eastern Anatolia and its depiction in popular culture, see Ahmet Özcan, 'Les derniers bandits kurdes de la Turquie moderne: Analyse des soulèvements individuels “spontanés" kurdes ou le banditisme contre l'État-nation turc', Dans L'Homme et la Société 1-2 (187-8) (2013): 155-81.

128 To see how the Ottoman state interacted with and co-opted bandits in Anatolia during the early modern era, see Karen Barkey, Bandits and Bureaucrats: The Ottoman Route to State Centralization (Ithaca, NY: Cornell University Press, 1994). For the troublesome military history of how the Ottoman Empire settled for 'a federative, mercenary, or paramilitary force for the maintenance of its remaining territories on the Danube and in Greater Syria', see Virginia H. Aksan, 'Mobilization of Warrior Populations in the Ottoman Context, 1750-1850', in Fighting for a Living: A Comparative Study 
onwards, as the bureaucratisation of state apparatus demanded far-reaching control and coercion, the imperial state began to challenge the autonomy of warlords on the frontiers, while also continuing to use them against the state's enemies. ${ }^{129}$ The different types of Ottoman irregulars, for example, were all grouped together under the notorious umbrella term başıbozuk, which the state regularly marshalled in times of conflict throughout the nineteenth century. ${ }^{130}$ The Ottoman state's co-optation of such indigenous militias constituted a challenge to later nationalist representations that idealised the role of warlords and brigands in their respective national spheres. In the Greek case, the Ottoman state's indigenous militias, the so-called armolotoi, were idealised as national heroes after Greek independence, but their rogue conduct similarly continued to be a risk to the fledgling Greek state. ${ }^{131}$ Contrary to their projection as proto-nationalist armed forces, many of these militias had in fact a mixed ethnic-religious membership. Nevertheless, the increased recruitment of certain ethnic groups - most notably Albanians and Circassians as well as Kurds in Anatolia - as irregulars

of Military Labour 1500-2000 (Amsterdam: Amsterdam University Press, 2013), 351.

${ }^{129}$ Frederick F. Anscombe, 'Continuities in Ottoman Centre-Periphery Relations, 17871915', in A. C. S. Peacock (ed.), The Frontiers of the Ottoman World (Oxford: Oxford University Press, 2009), 235-52.

${ }^{130}$ Literally meaning 'broken head' in the sense that they were unruly in their armed conduct, the term başıbozuk was popularised by foreign observers, such as Edward Vizetelly, The Remininiscences of a Bashi-Bazouk (Bristol: J. W. Arrowsmith, 1897), as well as by those who depicted Ottoman rule as alien and unjust, such as in Avetis Nazarbek, 'Zeitun', The Contemporary Review 69 (January 1896): 513-28. For the Ottoman military's problems with 'irregulars-cum-bandits', see Uğur Bayraktar, 'From Salary to Resistance: Mobility, Employment, and Violence in Dibra, 1792-1826', Middle Eastern Studies 54(6) (2018): 878-900.

${ }^{131}$ John S. Koliopoulos, 'Brigandage and Irredentism in Nineteenth-Century Greece', in Martin Blinkhorn and Thanos Veremis (eds), Modern Greece: Nationalism and Nationality (Athens: SAGE-ELIAMEP, 1990), 67-102; Achilles Batalas, 'Send a Thief to Catch a Thief: State-Building and the Employment of Irregular Military Formations in MidNineteenth-Century Greece', in Diane E. Davis and Anthony W. Pereira (eds), Irregular Armed Forces and Their Role in Politics and State Formation (Cambridge: Cambridge University Press, 2003), 149-77; Gerassimos Karabelias, 'From National Heroes to National Villains: Bandits, Pirates and the Formation of Modern Greece', in Stephanie Cronin (ed.), Subalterns and Social Protest: History from Below in the Middle East and North Africa (London: Routledge, 2008), 263-83. 
further sharpened identity politics across different frontiers of the Ottoman Empire. ${ }^{132}$

The shared organisational features of such bands of rebels and bandits became their key characteristics, blurring their categorical differences in terms of their political legitimacy. Both rebels and bandits were organised in small armed groups (cheta in Slavic and çete in Turkish) with a chain of command subordinate to a charismatic leader, navigating across a frontier territory, if not rural hinterlands. Such bands drew from an existing repertoire of rural brigandage and frontier warfare. Primarily recruiting bachelors, landless peasants, refugees and deserters to their cause, they could also attract adventurers and mercenaries. The term çete denoted multiple meanings over time, ranging from a band of guerrilla warriors to more contemporary usage indicating gangster violence and deep-state networks. ${ }^{133}$ According to an Ottoman military manual for irregular warfare from 1909, there were two categories of çete: first, the 'roadside criminals' and, second, those 'in pursuit of national and political intentions'. ${ }^{134}$ This differentiation between political rebels and criminal bandits is common elsewhere, too. In Russian Turkestan, for instance, Enver Paşa had joined the insurgency of the Basmachi, literally meaning 'raider'. ${ }^{135}$ 'It is necessary to distinguish between two classes of Basmachis in

${ }^{132}$ Frederick F. Anscombe, 'Albanians and "Mountain Bandits"', in Frederick F. Anscombe (ed.), The Ottoman Balkans, 1750-1830 (Princeton, NJ: Markus Wiener, 2006), 87-113; Ryan Gingeras, Sorrowful Shores: Violence, Ethnicity, and the End of the Ottoman Empire, 1912-1923 (Oxford: Oxford University Press, 2009), 23-36; Janet Klein, The Margins of Empire: Kurdish Militias in the Ottoman Tribal Zone (Stanford, CA: Stanford University Press, 2011); Antonio Ferrara and Niccolò Pianciola, 'The Dark Side of Connectedness: Forced Migrations and Mass Violence between the Late Tsarist and Ottoman Empires (1853-1920)', Historical Research 92(257) (2019): 608-31; Caner Yelbaş1, The Circassians of Turkey: War, Violence and Nationalism from the Ottomans to Atatürk (London: I. B. Tauris, 2019).

${ }^{133}$ For an excellent conceptual history of the term, see Polat Safi, 'Üç Tarz-1 Çete', Kebikeç 34 (2012): 85-105.

134 Ömer Fevzi, Muhafâza-i Âsâyişe Mémûr Zabitanın Vezâifi: Usûl-i Ta'kib-i Eşkiyâ' ve Çete Muhârebeleri (Istanbul: Matbaa-i İkbal, 1325 [1909/1910]), 20-9, quoted in Safi, 'The Ottoman Special Organization', 109.

135 On the origins of the Basmachi revolt, see Yulia Uryadova, 'Bandits, Terrorists, and Revolutionaries: The Breakdown of Civil Authority in the Imperial Ferghana Valley, 1905-1914', PhD thesis, University of Arkansas, 2012. 
Ferghana', noted a British observer, 'The genuine political Basmachis, the original Soviet rebels against Soviet rule ... On the other hand, there are the purely bandit Basmachis ... who terrorise the countryside. ${ }^{136}$ While the shared organisation made them appear identical, the criminalising discourse also served state interests that tried to deny and delegitimise the politicisation of rebels-cum-bandits. ${ }^{137}$

In the late nineteenth century, however, çete came to describe a new form of rogue conduct, readily equated with the Ottoman term komitadji (in Turkish: komitacı or komiteci). Even though the term is originally an Ottoman-Turkish expression used by government officials with the literal meaning of 'committee man', the word in fact still exists in various Balkan languages, identifying either an individual partisan fighter or agency on behalf of a revolutionary committee. The term komitadji uniquely signifies the merging of rural and urban forms of transgressive politics into a shared repertoire of rogue conduct. On the one hand, the rural repertoire - the formation of small units of brigands and the elaboration of tactics of irregular warfare and the mobilisation strategies of peasants - were locally rooted processes that served a variety of political agendas. On the other hand, a new urban repertoire combined the organisational features of secret societies and political parties with the tactics of terrorism and 'propaganda of the deed' - complete with the political socialisation of followers through collective action among workers and youth. This led to a new type of urban warfare, whereby bomb attacks and political assassinations could generate new levels of pressure on political regimes, most notably as in the raid on the Ottoman

136 Quoted in Şuhnaz Yilmaz, 'An Ottoman Warrior Abroad: Enver Paşa as an Expatriate', Middle Eastern Studies 35(4) (1999): 57-8. For conflicting narratives of the Basmachi in post-Soviet countries, see Kirill Nourzhanov, 'Bandits, Warlords, National Heroes: Interpretations of the Basmachi Movement in Tajikistan', Central Asian Survey 34(2) (2015): 177-89.

137 Yenen, 'Banditen'. For instance, sabotage attacks on Ottoman railways by the Macedonian Revolutionary Committee were referred to in Ottoman bureaucratic language as conducted by 'bandits (eşkiya) or "trouble makers" (fesatciler)'. Peter Mentzel, 'Accidents, Sabotage, and Terrorism: Work Hazards on Ottoman Railways', in Colin Imber, Keiko Kiyotaki and Rhoads Murphey (eds), Frontiers of Ottoman Studies: State, Province, and the West, (London: I. B. Tauris, 2005), vol. 2, 237. 
Bank in Istanbul in $1896 .{ }^{138}$ Successful and failed assassination attempts against presidents, monarchs and ministers, including Tsar Alexander II (1881), Bulgarian prime minister Stefan Stambolov (1895), Nasser-al-Din Shah (1896), Empress Elisabeth of Austria (1898) and Sultan Abdülhamid II (1905), demonstrated the vulnerability of public rulers in the face of the new urban repertoire of transgressive politics, but also fed into bureaucratic insecurities vis-à-vis new political challenges. ${ }^{139}$

The emergence of this new modus operandi, we argue, was the product of new opportunity structures for contention that emerged out of the structural ruptures in the late nineteenth century. Increased access to military and civilian education since the mid-nineteenth century had given birth to a class of disgruntled individuals whom the Ottoman ancien régime was unable to absorb. Rogues were borne out of this group of individuals who were denied access to the metropole and positions of power. They would find opportunities elsewhere, particularly after the balance of power shifted in Europe thanks to the rise of Germany as a Great Power, which heralded new forms of imperialism in the last two decades of the nineteenth century. ${ }^{140} \mathrm{In}$ this age of territorial scramble, an increasingly competitive political climate opened up new political opportunities for transgressive actors, particularly in the frontiers of empires where interstate competition and local rivalries were at their fiercest. Their genre of transgressive politics included a particular brand of radicalism that called for land reform, social justice and protection of rights, which appealed to the disgruntled rural populations who were hard hit by the price recession due to the Long Depression (1873-1896), and to those urban workers suffering from an unstable labour market. ${ }^{141}$ It was

138 Bloxham, 'Terrorism and Imperial Decline', 309-10.

139 Richard Bach Jensen, 'Daggers, Rifles, and Dynamite: Anarchist Terrorism in Nineteenth Century Europe', Terrorism and Political Violence 16(1) (2004): 116-53. On reactions of the Ottomans, see İlkay Yılmaz, Serseri, Anarşist ve Fesadın Peşinde: II. Abdülhamid Dönemi Güvenlik Politikaları Ekseninde Mürur Tezkereleri, Pasaportlar ve Otel Kayıtları (Istanbul: Tarih Vakfı Yurt Yayınları, 2014); İlkay Yılmaz, 'Propaganda by the Deed and Hotel Registration Regulations in the Late Ottoman Empire', Journal of the Ottoman and Turkish Studies Association 4(1) (2017): 137-56.

${ }^{140}$ Hobsbawm, The Age of Empire, 56-61; Benedict Anderson, Under Three Flags: Anarchism and the Anti-Colonial Imagination (London: Verso, 2000), 4.

${ }^{141}$ Linda Schatkowski Schilcher, 'The Great Depression (1873-1896) and the Rise of Syrian 
the coalescence of these three interrelated ruptures in the mid-1880s that ultimately enabled transgressive action outside the routine and normativity of conventional politics. ${ }^{142}$

Crucially, there were many examples to follow. While the IMRO model was a source of inspiration for Enver and his fellow Ottoman-Muslim revolutionaries, the Armenian revolutionary organisations provided templates of revolutionary activism across the Balkans, Anatolia, and Russian and the Iranian Caucasus. In Qajar Iran, the Armenian revolutionaries played a prominent role in the dissemination of the revolutionary repertoire, which merged with Muslim reform policies proposed by Iranian constitutionalists after the Tobacco Revolt of 1890-2. ${ }^{143}$ In Persian, the term anjoman came to denote both political organisations and secret societies during the constitutional struggle. ${ }^{144}$ For the Young Turk volunteers who were dispatched to the Caucasus to support the Iranian constitutionalists and collaborate with

Arab Nationalism', New Perspectives on Turkey 6 (1991): 167-89; Donald Quataert, 'The Age of Reforms', in Halil İnalcik and Donald Quataert (eds), An Economic and Social History of the Ottoman Empire, Vol. 2: 1600-1914 (Cambridge: Cambridge University Press, 1994), 856, 871; Joel Beinin, Workers and Peasants in the Modern Middle East (Cambridge: Cambridge University Press, 2001), 44-70; Ilham Khuri-Makdisi, The Eastern Mediterranean and the Making of Global Radicalism (Berkeley, CA: University of California Press, 2010); Nadir Özbek, 'The Politics of Taxation and the "Armenian Question” during the Late Ottoman Empire, 1876-1908', Comparative Studies in Society and History 54(34) (2012): 770-97; Kostopoulos, 'Land to the Tiller'.

${ }_{142}$ All the (in)famous revolutionary organisations on the frontiers of the Ottoman Empire date back to this period. The Armenian Hunchaks were founded in 1887, the Committee of Union and Progress (CUP) in 1889, Dashnaktsutyun (aka ARF) in 1890, Internal Macedonian Revolutionary Organization (IMRO) in 1893, and the External Macedonian Revolutionary Organization in 1895.

${ }^{143}$ Houri Berberian, 'Nest of Revolution: The Caucasus, Iran, and Armenians', in Rudi Matthee and Elena Andreeva (eds), Russians in Iran: Diplomacy and Power in Qajar Era and Beyond (London: I. B. Tauris, 2018), 95-121; Moritz Deutschmann, 'Cultures of Statehood, Cultures of Revolution. Caucasian Revolutionaries in the Iranian Constitutional Movement, 1906-1911', Ab Imperio 2 (2013): 165-90; Mangol Bayat, Iran's First Revolution: Shi'ism and the Constitutional Revolution of 1905-1909 (Oxford: Oxford University Press, 1991), 76-105.

144 Sohrabi, Revolution and Constitutionalism, 367-77; Bayat, Iran's First Revolution, 70-5, 111-17, 146-59, 161-8; Nezam-Mafi M. Ettchadieh, 'Origin and Development of Political Parties in Persia 1906-1911', PhD thesis, University of Edinburgh, 1979, 248-88. 
Armenian revolutionaries, the terms anjoman and komitadji were understood to refer to the same type of rogues. ${ }^{145}$ Even though methodological nationalism may portray them as the embodiments of irreconcilable nationalisms within an empire, they in fact cooperated as much as they competed with one another, ${ }^{146}$ just as empires cooperated and competed with one other in controlling the komitadjis, anarchists and socialists. ${ }^{147}$

Not only constitutional revolutions, but also wars - especially the total war experience of the Balkan Wars and later the First World War - offered new opportunities for the komitadjis. True to their guerrilla culture, they participated in conventional wars and re-entered the sphere of state control and co-optation. Leon Trotsky, as a war correspondent during the Balkan Wars, revealed how ' $[\mathrm{t}]$ he komitadjis were organized already before the war, in different ways in different areas ... When war came, they were attached to particular army units for outpost duty and scouting ... ${ }^{148}$ Similarly, to all intents and purposes, the Ottoman army's special operations organisation, Teşkilatı Mahsusa, was a komitadji organisation that grew out of the unconventional warfare experience across the Ottoman frontiers, turning into the CUP regime's paramilitary and parapolitical enforcer. ${ }^{149}$ This convolution of rogue conduct and interstate warfare in the Balkans not only affected

145 Fethi Tevetoğlu, Ömer Naci (Ankara: Kültür ve Turizm Bakanlığı, 1987), 105. For more background, see Farzin Vejdani, 'Crafting Constitutional Narratives. Iranian and Young Turk Solidarity 1907-09', in H. E. Chehabi and Vanessa Martin (eds), Iran's Constitutional Revolution: Popular Politics, Cultural Transformations and Transnational Connections (London: I. B. Tauris, 2010), 319-40.

146 Duncan M. Perry, 'The Macedonian Revolutionary Organization's Armenian Connection', Armenian Review 42(5) (1989): 61-8; Garabet K. Moumdjian, 'Rebels with a Cause: Armenian-Macedonian Relations and Their Bulgarian Connection, 1895-1913', in M. Hakan Yavuz and Isa Blumi (eds), War and Nationalism: The Balkan Wars, 1912-1913, and Their Sociopolitical Implications (Salt Lake City, UT: University of Utah Press, 2013), 132-75; Berberian, Roving Revolutionaries, 131-2.

147 Richard Bach Jensen, 'The International Campaign Against Anarchist Terrorism, 18801930s', Terrorism and Political Violence 21(1) (2009): 89-109.

${ }^{148}$ Leon Trotsky, The Balkan Wars, 1912-13: The War Correspondence of Leon Trotsky, ed. George Weissman and Duncan Williams (New York: Pathfinder Press, 1980), 120.

149 Uğur Ümit Üngör, 'Paramilitary Violence in the Collapsing Ottoman Empire', in Robert Gerwarth and John Horne (eds), War in Peace: Paramilitary Violence in Europe after the Great War (Oxford: Oxford University Press, 2012), 164-83. 
the making of states but also contributed to the forging of nations. ${ }^{150}$ Even the First World War was triggered by rogue conduct in a contested frontier of empires, when a group of Bosnian-Serbian revolutionaries, who were associated with the Black Hand Society and trained by the Serbian military intelligence, assassinated the Habsburg crown prince in Sarajevo on 28 June 1914. ${ }^{151}$ After the First World War, the contentious repertoire of rogues continued to travel from the Balkans to the Middle East. A British intelligence officer described Arab uprisings in 1920 as 'insurrections resorting to the avowed tactics of guerrilla and cemitadji [sic] warfare'. ${ }^{152}$ Transgressive politics is always a product of its time and place. War and revolution conditioned the emergence of rogues across the frontiers of empires; as was the case the other way around as well.

\section{Rogue Conduct: Search for a Culture of Agency}

From frontiers of empires to the centres of power, rogues played important roles in the social construction of identities in the Balkans, the Middle East and the Caucasus. Neo-Weberian perspectives on the role of war and violence, however, fail to account for cultural and ideological dimensions. ${ }^{153}$ While

${ }^{150}$ Mulaj Klejda, 'War and State Making at the End of Empire: Ottoman Collapse and the Formation of the Balkan States', Peace \& Change: A Journal of Peace Research 41(4) (2016): 539-66; M. Hakan Yavuz, 'Warfare and Nationalism: The Balkan Wars as a Catalyst of Homogenization', in M. Hakan Yavuz and Isa Blumi (eds), War and Nationalism: The Balkan Wars, 1912-1913, and Their Sociopolitical Implications (Salt Lake City, UT: University of Utah Press, 2013), 31-84; Siniša Malešević, 'Wars that Make States and Wars that Make Nations: Organised Violence, Nationalism and State Formation in the Balkans', European Journal of Sociology 53 (2012): 31-63.

151 Tetsuya Sahara, 'The Making of "Black Hand" Reconsidered', Istorija 20. veka 34(1) (2016): 9-29; Christopher M. Clark, The Sleepwalkers: How Europe Went to War in 1914 (London: Penguin, 2013), 3-64. In many ways, the pre-war Balkans foreshadowed the paramilitary violence in Europe during the aftermath of the First World War. John P. Newman, 'The Origins, Attributes, and Legacies of Paramilitary Violence in the Balkans', in Robert Gerwarth and John Horne (eds), War in Peace: Paramilitary Violence in Europe after the Great War (Oxford: Oxford University Press, 2012), 145-62.

152 Quoted in Isaiah Friedman, British Miscalculations: The Rise of Muslim Nationalism, 19181925 (New Brunswick, NJ: Transaction, 2012), 56.

${ }_{153}$ Malešević, The Sociology of War and Violence, 79-80. 
nationalism as the growing ideology of the time certainly needs attention, ${ }^{154}$ one must be wary of methodological nationalism which often treats nationalism as less a subject of study than as a tool of analysis. In avoiding the latter, we see nationalism as part of the same dynamics of modernity that shaped the age of rogues on the frontiers of empires. This was when print media, cultural associations, secret societies and political parties created new public spheres to make collective claims on behalf of nationalist imaginations. ${ }^{155}$ Yet nationalism is only one of several global ideologies, such as anarchism, socialism and radicalism, all of which had a considerable impact on both Muslim and non-Muslim intelligentsia in imperial frontiers. ${ }^{156}$ Notions of radical reform, social revolution and/or territorial claims co-existed with material interests in rents derived from racketeering and brutal cultures of violence.

The historical significance of the IMRO, Enver, and many others from their creed and generation lay not in the consistency of their ideological positions or in the sharpness of their discursive articulations, but rather in their proclivity to contentious and transgressive action in pursuit of their political interests. In approaching the latter, we reject the notion of violence as a degree of conflict, but consider it as a form of contentious and formative interaction that is context-dependent. ${ }^{157}$ It is neither the strength of

${ }^{154}$ Umut Uzer, An Intellectual History of Turkish Nationalism: Between Turkish Ethnicity and Islamic Identity (Salt Lake City, UT: The University of Utah Press, 2016).

155 For a comparative approach, see Fatma Müge Göçek, 'Decline of the Ottoman Empire and the Emergence of Greek, Armenian, Turkish and Arab Nationalisms', in Fatma Müge Göçek (ed.), Social Constructions of Nationalism in the Middle East (Albany, NY: State University of New York Press, 2002), 15-84.

156 Nationalism as a framework shaped the study of socialists and anarchists in the Ottoman world. For a pioneering overview, see Mete Tunçay and Erik Jan Zürcher (eds), Socialism and Nationalism in the Ottoman Empire: 1876-1923 (London: I. B. Tauris, 1994). On the cosmopolitism of anarchism beyond nationalism, see Axel B. Çorlu, 'Anarchists and Anarchism in the Ottoman Empire, 1850-1917', in Selim Karahasanoğlu and Deniz C. Demir (eds), History from Below: A Tribute in Memory of Donald Quataert (Istanbul: Istanbul Bilgi Üniversitesi Yayınları, 2016), 551-81. For the Levant, see Khuri-Makdisi, The Eastern Mediterranean. For anarchism's global dimension, see Steven Hirsch and Lucien van der Walt (eds), Anarchism and Syndicalism in the Colonial and Postcolonial World, 1870-1940: The Praxis of National Liberation Internationalism and Social Revolution (Leiden: Brill, 2010).

157 Rogers Brubaker and David D. Laitin, 'Ethnic and Nationalist Violence', Annual Review of Sociology 24 (1998): 426; Adria Lawrence, 'Driven to Arms? The Escalation to Violence in 
nationalist convictions nor the degree of exasperation that causes violence, while the resort to violence certainly leads to both. As Tolga U. Esmer demonstrated, the transgressive politics of the Ottoman state in the co-opting of rebels and bandits affected the culture of violence on the ground. ${ }^{158}$ Violence played into the boundary work of the construction of collective identities, too. 'Paramilitarism', noted Ryan Gingeras, 'was a political, economic, and social institution that enabled both statist and resistance factions to mobilize popular support'. ${ }^{159}$ The experience of paramilitary violence was therefore constitutive of militant expressions of nationalism. In an often-quoted passage by a Teşkilat-ı Mahsusa agent, the conduct of a komitadji was defined as 'the most extreme form of patriotism':

And the komitadji is a person who sacrifices everything, even his life, for the cause of the fatherland, who does not forsake anything, and who has renounced his whole being from head to toe. When it is necessary for the interests of this country and nation, he abandons compassion, if it is necessary to burn something, he burns, if there is a need to destroy, he destroys it all! He does not leave a stone on top of a stone or a head on top of a torso! $!^{160}$

Beyond violence, romantic visions of camaraderie and adventure similarly helped to shape identities. The komitadjis were 'modern knights of the round table' in the imagination of contemporary European observers critical of Ottoman rule over the Balkans. ${ }^{161}$ 'The ambition of every Macedonian boy in those days was to become a comitadji, to raise a beard, a mop of shaggy hair', as Ottoman-Macedonian-born American writer and US senator Stoyan Christowe remembered. ${ }^{162}$ The cult of a charismatic leader of a çete was another feature of constructing a collective identity. In the Balkans,

Nationalist Conflicts', in Erica Chenoweth and Adria Lawrence (eds), Rethinking Violence: States and Non-State Actors in Conflict (Cambridge, MA: MIT Press, 2010), 145.

158 Esmer, 'Economies of Violence'.

159 Gingeras, Sorrowful Shores, 6.

${ }^{160}$ Fuat Balkan, Komitacı: BJK'nin Kurucusu Fuat Balkan'in Anıları, ed. Turgut Gürer (Istanbul: Gürer Yayınları, 2008), 43, 45; quoted here from the English translation in Göçek, 'Decline of the Ottoman Empire', 92.

${ }^{161}$ Jan Gordon, A Balkan Freebooter: Being the True Exploits of the Serbian Outlaw and Comitaj Petko Moritch (London: Smith Elder, 1916), 243.

162 Stoyan Christowe, Heroes and Assassins (New York: R. M. McBride, 1935), 15. 
these leaders were called voivode. Popular admiration for voivodes and chetas was not restricted to the Christian population. Şevket Süreyya Aydemir, an Ottoman-Muslim born in Edirne in the Balkans in 1897, remembered from his childhood that it was their favourite game to play çete and komitadji wars with the neighbourhood children:

First, we chose kaptans and voivodas ... from among the strongest and bravest of the children, who then split up into groups. Those who took part in the game would turn back the edges of their fezes to make them look like the fur hats (kalpak) worn by Greek and Bulgarian bandits ... Instead of knives and guns, they stuck sticks and pieces of wood into their belts, and instead of bombs, they filled their pockets and sashes with stones. ${ }^{163}$

A very different but similarly formative childhood memory about the komitadji phenomenon comes from Minas Dersakissian who, as a young twelveyear-old Armenian boy, was put under detention by Ottoman officials on his way to the Armenian seminary in Jerusalem in 1907. In an interview in 1970, he recalled the impact of his unjust encounter with Ottoman authorities:

He tells me I am a 'Komitaji', a member of an 'Armenian terrorist group', a group I had never heard of, and, to say the least belong to. In fact, that incident sparks an interest in me to find out who those 'Komitajis' are, and later on in my life when I learned about the mission of this group, which was to fight by taking arms against all oppressive enemies of Armenia, be it Turkey or [Russia] which had occupied our motherland, Armenia, I too become a 'Komitadji', and a life-long member of the Armenian Revolutionary Federation, and actually took arms and fought against them. ${ }^{164}$

Under such state repression and surveillance, many komitadjis tapped into the cultural repertoire of Masonic secret societies that provided clandestine

163 Şevket Süreyya Aydemir, Suyu Arayan Adam, 7th edn (Istanbul: Remzi Kitabevi, 1979), 16, quoted here from the English translation in Andrew Mango, Atatürk (New York: Overlook Press, 2002), 12-13.

164 Vahak D. Sarkis, The Odyssey of an Armenian Revolutionary Couple: How They Survived the First Genocide of the 20th Century (Bloomington, IN: Xlibris, 2010), 26-7. 
support and shelter to some revolutionary movements. ${ }^{165}$ Masonic societies were also the context, where most komitadji organisations adopted the initiation and secrecy rituals, topped off with the fraternal principles drawn from the Carbonari-styled parties. In shaping identities and loyalties, transgressive politics commonly sacralised its own raison d'être. The CUP was vernacularly called the 'sacred society' (cemiyet-i mukaddes). The secret oath given to the revolutionary committee created terminal loyalty among members and commitment to political violence. ${ }^{166}$ In their initiation oath, the CUP, in copying other Balkan revolutionary committees, put their hand on a Qur'an, a dagger and a revolver. ${ }^{167}$ Even more, transgressive politics sacralised the violent self-sacrifice and political martyrdom. The cult of the feda' $i$, namely, the self-sacrificing volunteers, created a political culture based on killing and dying among Turks, Armenians, Iranians and Arabs. ${ }^{168}$

Returning to Tilly's dictum, it remains unanswered why and how subaltern forms of protection rackets continue to exist beneath and beyond state hegemony long after the formal monopolisation of legitimate means of violence - a point critically emphasised in the Frankfurt School's racket theory long before. ${ }^{169}$ While the state cannot exist without racketeers, racketeers can

165 Thierry Zarcone, 'Freemasonry and Islam', in Henrik Bogdan and J.A.M. Snoek (eds), Handbook of Freemasonry (Leiden: Brill, 2014), 233-57. The Young Turk networks in Salonica held their secret meetings in the Freemason lodges. M. Şükrü Hanioğlu, 'Notes on the Young Turks and the Freemasons', Middle Eastern Studies 25(2) (1989): 186-97.

166 Brown, Loyal unto Death, 74-86.

167 This oath ritual was later copied even by the Muslim Brotherhood in Egypt and Indian Muslims. Hanioğlu, Preparation for a Revolution, 218; Richard P. Mitchell, The Society of the Muslim Brothers, reprinted with new Introduction (New York: Oxford University Press, 1993), 206; Azmi Özcan, Pan-Islamism: Indian Muslims, the Ottomans and Britain (1877-1924) (Leiden: Brill, 1997), 157.

168 Khachig Tölölyan, 'Cultural Narrative and the Motivation of the Terrorist', Journal of Strategic Studies 10(4) (1987): 217-33.

169 The Frankfurt School's racket theory is based on scattered notes and references throughout Max Horkheimer's work, including Max Horkheimer, 'Theorie der Rackets', in Alfred Schmidt and Gunzelin Schmid Noerr (eds), Gesammelte Schriften 14: Nachgelassene Schriften 1949-1972 (Frankfurt: Fischer, 1988), 340; Max Horkheimer, 'Die Rackets und der Geist', in Gunzelin Schmid Noerr (ed.), Gesammelte Schriften 12: Nachgelassene Schriften 1931-1949 (Frankfurt: Fischer, 1985), 287-91. For a concise but illuminating reinterpretation of racket theory, see Olmo Gölz, 'The Dangerous Classes and the 1953 Coup in Iran: On the Decline of "lutigari” Masculinities', in Stephanie Cronin (ed.), 
exist without the state. In addressing this discrepancy, we need to reconsider statehood as a collective performance. Every organisation or social community performs statehood in one way or another. It was no surprise that both the IMRO and later the CUP functioned like 'para-states' within states. ${ }^{170}$

Historical and political anthropology show that other key features of statehood besides violence, such as control over territory and people, are similarly claimed by rebels and bandits when they control passages, tax the peasants, punish traitors and recruit followers. ${ }^{171}$ This para-state dimension of transgressive politics in rural areas and contentious frontiers was not much different in the microcosm of urban centres. Gangsters and strongmen emerged at the intersection of traditional and modern social communities in the neighbourhoods of towns and cities giving birth to the archetype of infamous gangsters across the modern Middle East (Turkish: kabadayz; Arabic: qabaday; Persian: luti)..$^{172}$ In the absence of a formal state or extra-legally on

Crime, Poverty and Survival in the Middle East and North Africa: The 'Dangerous Classes' since 1800 (London: I. B. Tauris, 2019), 187-9.

${ }^{170}$ For 'para-statehood', see Trutz von Trotha, 'Der Aufstieg des Lokalen', Aus Politik und Zeitgeschichte 28/29 (2005): 32-8, at: https://www.bpb.de/apuz/28956/der-aufstieg-deslokalen. See also Hans Joas and Wolfgang Knöbl, War in Social Thought: Hobbes to the Present (Princeton, NJ: Princeton University Press, 2013), 231.

${ }^{171}$ Brown, Loyal unto Death, 119-43. See also James C. Scott, The Art of Not Being Governed: An Anarchist History of Upland Southeast Asia (New Haven, CT: Yale University Press, 2009).

172 On Ottoman-Turkish kabadayı, see Yücel Yesilgöz and Frank Bovenkerk, 'Urban Knights and Rebels in the Ottoman Empire', in Cryille Fijnaut and Letizia Paoli (eds), Organized Crime in Europe: Concepts, Patterns and Control Policies in the European Union and Beyond (Dordrecht: Springer, 2004), 203-24; Roger A. Deal, Crimes of Honor, Drunken Brawls and Murder: Violence in Istanbul under Abdülhamid II (Istanbul: Libra, 2010); Noémi LévyAksu, Ordre et désordres dans l'stanbul ottomane (1879-1909) (Paris: Éditions Karthala, 2013), 253-76. On qabaday in the Arab world, see Philip Khoury, 'Abu Ali Al-Kilawi: A Damascus Qabaday', in Edmund Burke, III and David Yaghoubian (eds), Struggle and Survival in the Modern Middle East, 2nd edn (Berkeley, CA: University of California Press, 2005), 152-63; Guilain Denoeux, Urban Unrest in the Middle East: A Comparative Study of Informal Networks in Egypt, Iran, and Lebanon (Albany, NY: State University of New York Press, 1993), 77-80. On Iranian luti, see Gölz, 'The Dangerous Classes and the 1953 Coup in Iran'; Sivan Balslev, Iranian Masculinities: Gender and Sexuality in Late Qajar and Early Pahlavi Iran (Cambridge: Cambridge University Press, 2019), 34-42; Farzin Vejdani, 'Urban Violence and Space: Lutis, Seminarians, and Sayyids in Late Qajar Iran', Journal of 
its behalf, racketeers performed statehood in local quarters, social communities and craft guilds. The traditional agents of urban violence - military slaves, provincial notables, religious brotherhoods and guildsmen - were increasingly joined by neighbourhood gangs and worker's unions in mobilising collective action. ${ }^{173}$

Due to its intimacy, transgressive politics on the micro level often involves some form of gendered violence. As much as bands of brigands and militias cultivated their own idealised notions of manhood and brotherhood, they reaffirmed the hegemonic masculinity by subaltern means. Hegemonic masculinity subordinated not only women revolutionaries and 'weaker' men, but also sanctioned a code of honour that institutionalised gendered violence for the sake of protecting values and penalising wrongdoings. All kinds of rogues in the Balkans, the Middle East and the Caucasus constructed their own codes of honour - which awkwardly resembled each other. ${ }^{174}$ Where there is much talk about honour, sexual violence is commonly not far away. Hence, sexual violence was part of the repertoire of so many 'honourable' revolutionaries, irregulars, rebels, bandits and gangsters. Even more in episodes of demographic cleansing in the Balkans and Anatolia, sexual violence against women accompanied the brutal making of nations at the expense of others. ${ }^{175}$

Social History 52(4) (2019): 1185-211; Vanessa Martin, The Qajar Pact: Bargaining Protest and the State in Nineteenth Century Persia (London: I. B. Tauris, 2005), 113-32.

173 Juan R. I. Cole and Moojan Momen, 'Mafia, Mob and Shiism in Iraq: The Rebellion of Ottoman Karbala 1824-1843', Past \& Present 112 (1986): 112-43. Previous Ottoman reforms had broken with the power of many tribal and notable families in the urban towns of the Ottoman provinces. Hanna Batatu, The Old Social Classes and the Revolutionary Movements of Iraq: A Study of Iraq's Old Landed and Commercial Classes and of its Communists, Ba'thists, and Free Officers (Princeton, NJ: Princeton University Press, 1978), 217-20.

${ }^{174}$ For the continued references to this code of honour in contemporary Albanian organised crime, see Jana Arsovska, Decoding Albanian Organized Crime: Culture, Politics, and Globalization (Oakland, CA: University of California Press, 2015), 153-94.

175 Cathie Carmichael, Ethnic Cleansing in the Balkans: Nationalism and the Destruction of Tradition (London: Routledge, 2002), 68-73; Matthias Bjørnlund, “'A Fate Worse than Dying”: Sexual Violence during the Armenian Genocide', in Dagmar Herzog (ed.), Brutality and Desire: Genders and Sexualities in History (Basingstoke: Palgrave Macmillan, 2009), 16-58. See also Tolga U. Esmer, 'The Precarious Intimacy of Honour in Late 
Rogues maintained a complex culture of agency that unfolded locally, but nevertheless maintained a capacity to interact with transnational forces and shape political affairs elsewhere. By tapping into streams of rumours, channels of public discourse and popular myths, rogues could enhance their gravitational force in the communicative field of politics. ${ }^{176}$

In navigating in this age of rogues, the rebels, revolutionaries and racketeers were capable of channelling popular discontent, while embracing the ideological frames of the urban intelligentsia. In doing so, rogues consolidated their culture of agency through the deliberate use of political violence, sacralisation of politics and performances of para-statehood, complete with opaque ideological messages, obscure conspiracy theories and idealised notions of masculinity and fraternal autonomy that sought to mobilise a network of fighters, if not a mass of followers.

\section{Conclusion}

Neither the dynamics of transgressive politics nor the culture of agency of this period can be wholly grasped with static, linear, binary and normative concepts, which makes it necessary to cross conceptual frontiers. We accordingly propose the term rogue as an inclusive concept that not only signifies capability of transgression, but also denies any pre-configured historical consequence. Rogues could be both heroes and villains, rebels and rulers, revolutionaries and counter-revolutionaries. A 'rogue' is a transgressive political actor who operated especially in rural frontiers, but also in the urban microcosms of changing societies. Commonly engaged in political violence, rogues were often organised into small bands with a chain of

Ottoman Accounts of Para-militarism and Banditry', European Journal of Turkish Studies 18 (2014), at: http://ejts.revues.org/4873.

${ }^{176}$ Ever since, conspiracy theories in these regions not only trace the origin of transgressive politics to the age of rogues at the turn of the century, but also enjoy a popular reception in their respective societies. Esmer, 'Notes on a Scandal'; Alp Yenen, 'Elusive Forces in Illusive Eyes: British Officialdom's Perception of the Anatolian Resistance Movement', Middle Eastern Studies 54(5) (2018): 788-810; Ramazan Hakkı Öztan, 'Republic of Conspiracies: Cross-Border Plots and the Making of Modern Turkey', Journal of Contemporary History 56(1) (2021): 55-76. See also Cornel Zwierlein and Beatrice de Graaf, 'Security and Conspiracy in Modern History', Historical Social Research, Special Issue 'Security and Conspiracy in History, 16th to 21st Century', 38(1) (2013): 7-45. 
command subordinate to a charismatic leader. Through the propagation of ideals of masculine conduct, rogues were socialised by bonds of brotherhood and committed to codes of honour, which enabled a higher degree of group cohesion. Informed by a culture of secrecy, they gathered intelligence and operated through networks of secret cells in rural and urban areas alike. In order to access resources, rogues either tapped into existing smuggling rings or helped to create new illicit circuits, which provided them access to late nineteenth-century technologies of warfare. Equipped with such means of violence and well-versed with a repertoire of contentious politics, rogues performed acts of paramilitary and clandestine political violence against both state and non-state enemies. Through the strategic deployment of violence, rogues formed protection rackets which not only served to extract valuable economic resources outside state control, but also helped to create operational communities of solidarity vis-à-vis a world of violence that they helped to maintain. Although rogues were mostly autonomous in their local organisation and impulsive in their violent agency, they were at times dependent upon state sponsorship for the provision of precious resources and could therefore take advantage of lucrative opportunities offered by state patronage, but concomitantly they could also choose to eschew them at times.

Yet the emergence of rogues was context-specific. Their brand of transgressive politics particularly flourished on imperial frontiers whose inhabitants not only benefited from the newly opening avenues of socio-economic mobility, whether via education or emigration, but also suffered from demographic pressures and economic fluctuations in an increasingly globalised world as well as from interstate conflicts that generated successive waves of refugee crises. ${ }^{177}$ Taken as a whole, these transformations ultimately enabled transgressive politics, challenging the normative political paths that had otherwise defined anciens régimes. Yet these macro-level transformations ironically took place in an era known as the belle époque, a nostalgic moniker often associated with peace and stability in Europe. After all, this was a time of accelerated changes and increasing opportunities when human agency, social mobilisation and cultural change were understood to be major forces in the making of future states and societies. In this sense, the age of

177 Blumi, Foundations of Modernity, 78-109. 
rogues corresponds to a particular conjecture when 'the horizon of expectation' shifted considerably thanks to 'the idea that the future would not only change society at an increasing rate, but also improve it'. ${ }^{178}$ Drawing from a reservoir of shared historical experiences, and imbued with a belief in human capacity to re-order the state of things for a better future, rogues accordingly embraced activist agendas in a bid to change the unhappy course of history that, in their experience, had been increasingly unkind to their imagined civilisational order. In stark contrast to the optimism of the belle époque, hapless rogues took decidedly violent paths, foreshadowing the 'dark side' of the carnage to come during remainder of the twentieth century. ${ }^{179}$

As the following contributions in this volume will illustrate, rebels, revolutionaries and racketeers played central roles in the violent processes of imperial disintegration as it unfolded on the frontiers of the Ottoman, Habsburg, Romanov and Qajar empires. After the collapse of these empires, rogue conduct continued to have a complex afterlife. As paramilitary violence engulfed the post-First World War spaces, many of the rogues reconfigured themselves and began to take an active part in the 'nationalist' struggles that characterised the early 1920s. ${ }^{180}$ On an interstate level, the post-war uncertainties provided a range of opportunities to rogues who were willing to exploit them. ${ }^{181}$ On an organisational level, too, the debacles of the First World War removed the prominent leadership of revolutionary organisations

${ }^{178}$ Reinhart Koselleck, Futures Past: On the Semantics of Historical Time (New York: Columbia University Press, 2004), 270.

179 For a comparative historical project that explores this angle, see the ERC project titled 'The Dark Side of the Belle Époque: Political Violence and Armed Associations in Europe before the First World War', at: http://prewaras.eu. For the 'dark side' approach to the history of the twentieth century, see Michael Mann, The Dark Side of Democracy: Explaining Ethnic Cleansing (New York: Cambridge University Press, 2004); Philipp Ther, Die dunkle Seite der Nationalstaaten: 'Ethnische Säuberungen' im modernen Europa (Göttingen: Vandenhoeck \& Ruprecht, 2011).

${ }^{180}$ Michael Provence, 'Ottoman Modernity, Colonialism, and Insurgency in the Interwar Arab East', International Journal of Middle East Studies 43(2) (2011): 205-25; Alp Yenen, 'The "Young Turk Zeitgeist" in the Middle Eastern Uprisings in the Aftermath of World War I', in M. Hakan Yavuz and Feroz Ahmad (eds), War and Collapse: World War I and the Ottoman State (Salt Lake City, UT: University of Utah Press, 2016), 1181-216.

${ }^{181}$ Alp Yenen, 'Internationalism, Diplomacy, and the Revolutionary Origins of the Middle East's “Northern Tier”, Contemporary European History (forthcoming 2021). 
from power, such as Enver, allowing more junior and secondary figures to step in and thrive in the midst of the resistance to the Paris settlements. In places where the resistance was successful, such as Turkey, the former revolutionaries refashioned their rogue conduct into more formal forms of politics, rebranding their organisations but continuing to be rogues in essence. ${ }^{182}$ In so doing, they institutionalised transgressive politics into the emerging structures of national governance. Elsewhere, rogues continued to operate under the same revolutionary umbrella, as in the Balkans and Caucasus where the IMRO or ARF continued to exist and operate - and do so still to this day. The political violence in late Qajar Iran, too, shaped the culture of revolutionary violence in the twentieth century. ${ }^{183}$ As for the Middle East, the continuing territorial scramble for the region by the European powers provided opportunities to former Ottoman officers, some of whom turned rogue and thrived and criss-crossed post-Ottoman frontiers. ${ }^{184}$

182 Öztan, 'Republic of Conspiracies'.

${ }^{183}$ Mansour Bonakdarian, 'A World Born through the Chamber of a Revolver: Revolutionary Violence, Culture, and Modernity in Iran, 1906-1911', Comparative Studies of South Asia, Africa and the Middle East 25(2) (2005): 318-40.

${ }^{184}$ Parsons, The Commander; Provence, The Last Ottoman Generation; Laura Robson, The Politics of Mass Violence in the Middle East (Oxford: Oxford University Press, 2020). 